\title{
Paleolandscape Reconstruction Based on the Study of A Buried Soil of the Bronze Age in the Broadleaf Forest Area of the Russian Plain
}

\author{
Elena Aseyeva ${ }^{1, *}$, Alexander Makeev 2(1) Fatima Kurbanova ${ }^{2}$ (), Pavel Kust 2,3(D), \\ Alexey Rusakov ${ }^{4}$, Olga Khokhlova ${ }^{5}$, Evgeniy Mihailov ${ }^{6}$, Tatiana Puzanova ${ }^{1}$ \\ and Alexandra Golyeva ${ }^{7}$ \\ 1 Faculty of Geography, Lomonosov Moscow State University, Leninskiye Gori, GSP-1, \\ 119991 Moscow, Russia; puzanova@mail.ru \\ 2 Soil Science Faculty, Lomonosov Moscow State University, Leninskiye Gori, 1-12, 119991 Moscow, Russia; \\ makeevao@gmail.com (A.M.); fkurbanova403@gmail.com (F.K.); pavelkust@yandex.ru (P.K.) \\ 3 Dokuchaev Soil Institute, Russian Academy of Science, Pyzhevsky Lane, 7, 109017 Moscow, Russia \\ 4 Institute of Earth Sciences, Saint Petersburg State University, Universitetskaya nab 7-9, \\ 199034 Saint Petersburg, Russia; spp-06@mail.ru \\ 5 Institute of Physicochemical and Biological Problems of Soil Science, Russian Academy of Sciences, \\ Institutskaya Street, 2, 142290 Pushchino, Russia; olga_004@rambler.ru \\ 6 Chuvash State Institute of Humanitarian Sciences, Moscow Avenue, 29, 428015 Cheboksary, Russia; \\ mihaylov.evgeniy.1958@mail.ru \\ 7 Institute of Geography, Russian Academy of Sciences, Staromonetniy pereulok 29, 119017 Moscow, Russia; \\ golyeva@igras.ru \\ * Correspondence: aseyeva@mail.ru; Tel.: +7-9161356604
}

Received: 2 January 2019; Accepted: 22 February 2019; Published: 1 March 2019

\begin{abstract}
Late Holocene landscape evolution at the southern frontier of the forest belt of European Russia is studied based on detailed morphological, analytical and microbiomorphic research of a soil chronosequence that included a surface soil and a soil buried under the Bronze Age kurgan. Both soils (Folic Eutric Cambisols) are formed on similar geomorphic surfaces in the same parent material and in close proximity to each other. The soil morphology and the key analytical features are controlled by low-reactive parent material and imply close similarity of the present landscapes and those of the Bronze age. At the same time the morphological features show that the buried soil was influenced by the phase of weak aridization, which led to the formation of a dark mull humus horizon. Microbiomorphic assemblages (phytoliths, pollen) support the earlier conclusion that the soils of the study area had being developed mostly under forest vegetation.
\end{abstract}

Keywords: paleosol; kurgans; Abashevo archaeological culture; Subboreal; Atlantic; broadleaf forest; Cambisol; non-reactive parent material

\section{Introduction}

The Russian plain in the second half of the Holocene was inhabited by people of various civilizations. They left numerous earth burial mounds (kurgans) of the Middle to Late Holocene age. These ancient constructions, well documented by archaeologists, often preserve buried paleosols which contain clues about palaeoenvironments because many soil properties are associated with a particular environmental situation [1-5]. The wide geographical occurrence of burial mounds in the forest, dry-steppe and semi-desert zones, built over a span of many thousands of years, provides good opportunities for the application of palaeopedological approaches to generate an image of the 
spatial and temporal dynamics of the natural environment across the entire Russian plain. Numerous paleolandscape reconstructions of Holocene soils conducted in the forest-steppe, steppe, dry steppe and semi-desert areas of the Russian plain revealed distinct changes in soil features caused by alternating wet and relatively dry climatic cycles [1-8].

Previous studies on paleosols buried under kurgans of the Srubnaya (or the Timber-grave) culture from different periods (3900; 3800-3700 and 3700-3500 yrs BP) in the steppe areas of the Southern Cis-Urals showed distinct differences between the properties of paleosols and surface soils [9]. The reconstructions of paleoclimatic conditions allowed to relate the first phase (the period before 3900 yrs BP) to more arid and continental conditions, and later phases to more mild and humid environment, compared to the present situation. In the East European forest-steppe zone the contrasting trends in the development of zonal soils-chernozems and gray forest soils (Phaeozems and Luvisols) - were recorded. Paleopedological, radiocarbon and archeological data collected in this region revealed two main Holocene stages of pedogenesis: a humus accumulation (steppe) stage during the early and middle Holocene, followed by a humus degradation (forest) stage during the late Holocene. Likely, in the adjacent forested region similar trends have occurred, as some typical forest soils (Retisols) display relic features [10]. Radiocarbon dating of erosional landform deposits in the mixed forest zone of the Russian plain supports this idea and indicates that the southern part of the forest belt underwent two phases of high erosion around 4000-5000 [10-12] and 7000-8000 yrs BP [10]. The research confirmed that that these phases of high erosion were not caused by human activities, but most likely are related to the climatic changes [11,12].

The paleoclimatic rhythms show a correlation with sustained human migrations [13,14], particularly long-distant movings, or folk migrations [15]. Archeological studies in southern Europe revealed that stages of cooling, in particular around $4000 \mathrm{yrs} \mathrm{BC}$, and desiccation of climate conditions during 3300-3100 yrs BC were accompanied by an increased mobility of the local population, migrating to other regions [15]. Prominent shifts in cultural settings were also registered about 2500 yrs BC in Eastern Europe, in particular in the Middle Volga region where the resettlement of cattle-breeding tribes of the Abashevo culture (2500-1900 yrs BC) with the traditions of the Late Bronze Age occurred [15,16]. The "pull" factors that attracted the cattle-breeding population to the southern frontier of the forest belt are still unclear [16] and the contribution of climate-change impact on the Abashevo culture penetration into this region is discussible. The aim of the present research, conducted at one of the Abashevo burial sites in the Middle Volga region (Figure 1), is to reconstruct the evolutionary trends in soil development and to detect possible changes in environmental conditions, by revealing and comparing environmental pedo-signatures in a Bronze age soil buried under an Abashevo kurgan and a surface soil developed in similar lithological and geomorphic conditions.

Parent material together with geomorphic conditions represent the passive environmental factors setting the "environmental stage" for more active factors governing pedogenic processes [17]. The parent material of the study site, including its texture and mineralogy, turned out to be very different from the decalcified loess occurring throughout the surrounding region. Hence, studying the soils, developed in uncommon parent material resulted in an additional aim of the study - to evaluate their reflectiveness of environmental signals, and the possibilities of their use for paleoenvironmental reconstructions.

\section{Study Area}

The study was conducted in the vicinity of Tsivilsk (Figure 1a-c), situated in the forest zone of the Middle Volga region (Chuvashia Republic, Russian Federation). The examined paleosol is located in the Taushkasy kurgan cemetery dated by archeologists to the 3rd- or beginning of the 2nd millennium $\mathrm{BC}$ [18]. The kurgan cemetery occupies the interfluve area on the right bank of the Maly Tsivil river and counts more than 50 kurgans, arranged in three separate groups. Within the groups, the kurgans, 9-10 $\mathrm{m}$ in diameter, are located densely together under broadleaf forest vegetation and have heights ranging from 1 to $5 \mathrm{~m}$. The mounds have two types of shapes, being either circular or elongated. 
Geomorphologically, the area of the Taushkasy kurgan cemetery belongs the northern part of the Volga Upland, known as the Chuvash plateau, which is confined to the large protrusion of the Precambrian basement in the western part of the Volga-Ural arch. Within the study area the plateau represents an elevated upland terrain with heights predominant between 150-180 m a.s.1. The plateau has long denudation slopes, dissected by deep gullies, dry U-shaped valleys as well as active river valleys. The upper part of the sedimentary cover is composed of Upper Permian sedimentary rocks overlain by Quaternary deposits [19]. The pre-Quaternary sedimentary rocks are mostly sands containing lenses of sandstones and conglomerates, clays and siltstones. Sands and sandstones are greenish-pinkish-gray, sometimes reddish-brown, polymictic and fine-grained. Mottled clays and siltstones usually occupy the upper section of the pre-Quaternary sedimentary layer and often contain interlayers of sandstones [19]. In the study area, weathered sandstone slabs were found rather close to the surface, at depths ranging from 60 to $150 \mathrm{~cm}$. At the study site, soil parent material mostly consists of derivatives of the Permian sedimentary rocks (sandy loams, loams with pebbles, clays and sands) [20], however in the wider surroundings soils have developed in loessic deposits.
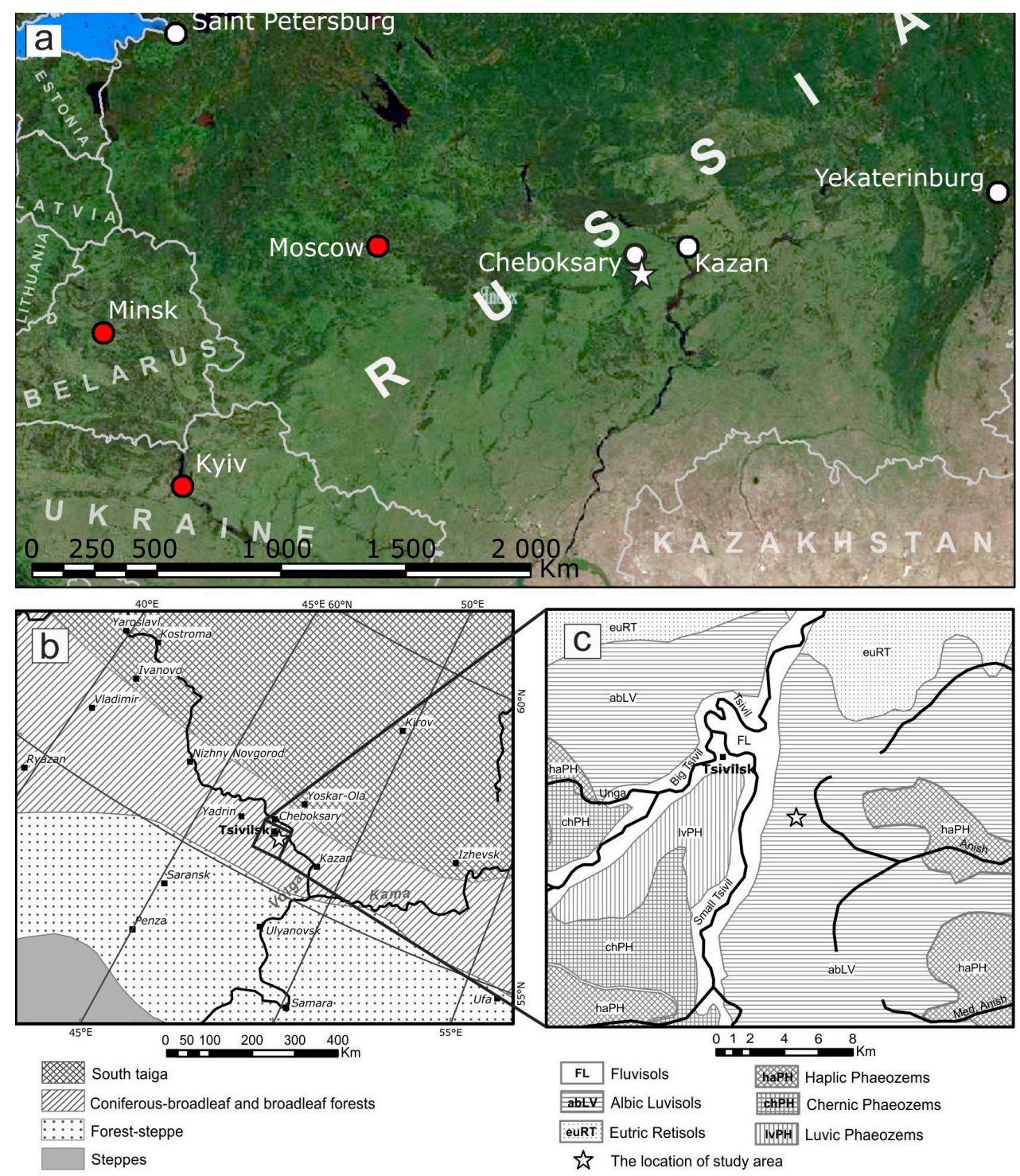

Figure 1. Location maps of the study area. (a) Regional-scale map; (b) Vegetation zones of the central part of the Russian Plain (modified after [21]); (c) Soil contours in the vicinity of Tsivilsk according to the State Soil Map of the Soviet Union 1:1,000,000 [22]. Reference Soil Groups according to IUSS Working Group WRB [23]. 
The climate of the study area is temperate continental, characterized by a mean January temperature of $-12.4{ }^{\circ} \mathrm{C}$ and a mean July temperature of $+19.4{ }^{\circ} \mathrm{C}$ [24]. The annual precipitation/ evaporation ratio equals 1.2, which characterizes the climate of the study area as humid; however, the average annual precipitation $(540 \mathrm{~mm}$ ) is less compared to the areas located on the same latitudes more to the west. In the second half of the winter the soil is usually frozen to a depth of $100 \mathrm{~cm}$, while the snow cover in recent years varies between $30-45 \mathrm{~cm}$. The maximum precipitation is observed in July $(60-70 \mathrm{~mm})$.

The typical vegetation occupying the uplands and slopes in the study area is broadleaf forest. The characteristic mature trees in the tree canopy include lime (Tilia cordata), oak (Quercus robur) and acer (Acer platanoides). The top layer of understory is formed by elm (Ulmus laevis), while the shrub layer commonly includes Sorbus aucuparia and Corylus avellana. The herbaceous layer is well developed and very diverse, including typical nemoral species such as Aegopodium podagraria, Carex sylvatica, Asarum europaeum, Convallaria majalis, Lathyrus vernus, Stellaria holostea, and Mercurialis perennis.

The common soils of the study site according to the State Soil Map [22] are gray forest soils (Luvisols, according to IUSS Working Group WRB [23]); however, the soil pattern of the study area is very complex and includes contrasting soils like Retisols and Phaeozems (Figure 1c). Variation in parent material seems to be the major factor controlling soil formation and the occurrence of different soil types.

\section{Methods}

The buried soil ( $\left.\mathrm{N} 55^{\circ} 51^{\prime} 49^{\prime \prime}, \mathrm{E} 47^{\circ} 31^{\prime} 19^{\prime \prime}\right)$ was studied in upland position at the elevation of $150 \mathrm{~m}$ a.s.l. under a kurgan of the southwestern group in the Taushkasy kurgan cemetery, in close proximity to the sides of the Maly Tsivil River valley. The kurgan mound (Figure 2) had a preserved height of 1.7-2 m, a circular shape and a flattened apex. Its diameter at the base reaches 7-8 meters. The kurgan was explored by archeologists in 1927 [18], however the excavation technique ("well" method), commonly used in early archeological studies, did not affect the major part of the kurgan; the disturbances could be detected only in its the central part. We also drilled boreholes in five other kurgans nearby, which confirmed the morphological identity of the ancient constructions and the similarity of the upper horizons of the buried soils.

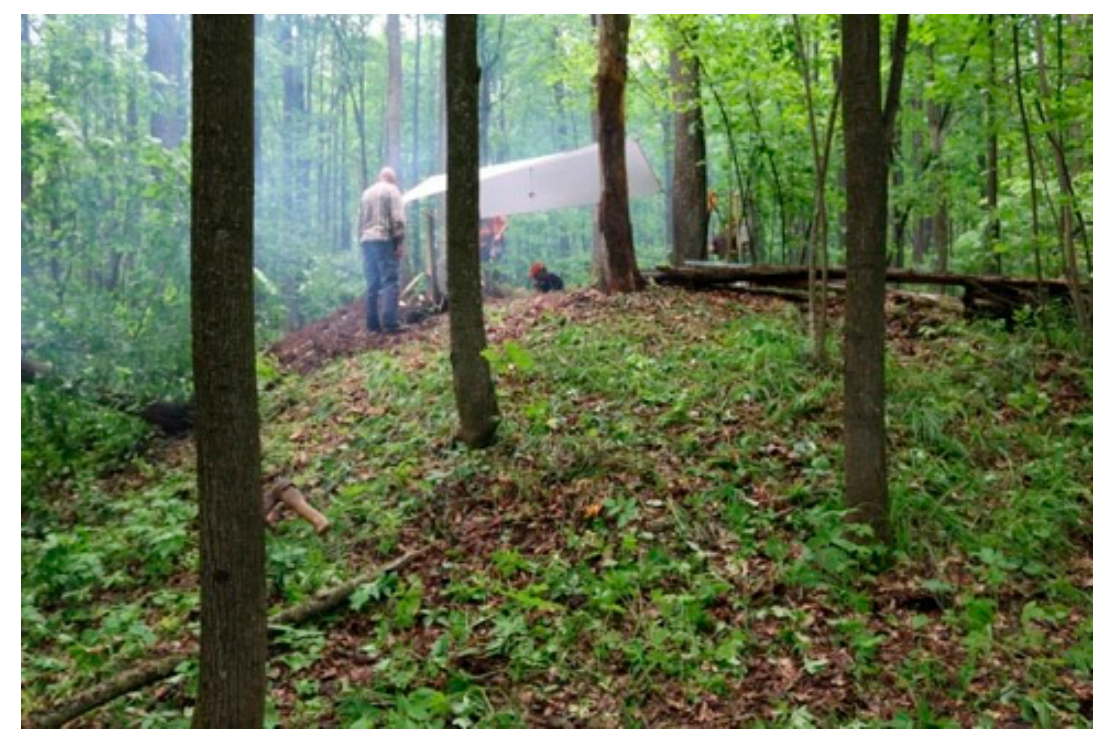

Figure 2. General view on the burial mound and the broadleaf forest vegetation of the study site.

The surface soil ( $\mathrm{N} 55^{\circ} 51^{\prime} 51^{\prime \prime} \mathrm{E} 47^{\circ} 31^{\prime} 19^{\prime \prime}$ ) was chosen on same geomorphic surface ( $24 \mathrm{~m}$ to the north from the buried soil) following a preliminary study of the parent material in 10 soil pits along a regular grid within a radius of $500 \mathrm{~m}$ around the kurgan, to ensure that any possible differences in soil features between the buried soil and the present-day surface soil could relate to differences 
between modern climatic parameters and those in the past, thus showing the Late Holocene trend in both climatic and vegetation changes in the study area. The measured difference in elevations between the upper limits of the buried and surface soils was less than $1 \mathrm{~m}$. The parent material of the two soils was nearly the same, and the underlying bedrock occurred at identical depth of $130 \mathrm{~cm}$.

Soil features were described according to the FAO Guidelines for Soil Description [25] and identified using the WRB [23]. The thickness of soil horizons was measured on three walls in 10-15 cm intervals. Micromorphological features were examined in thin sections of undisturbed oriented samples under plain and polarized light at 40-200-fold magnification using a polarizing microscope "Olympus BX51" (Olympus, Tokyo, Japan) of the V.V. Dokuchaev Soil Institute center. Olympus "StreamBasic" software was applied for capturing and image processing. In total, 13 thin sections were described based on the definitions and terminology of Stoops [26].

Laboratory analyses were performed on samples taken equidistantly $(10 \mathrm{~cm}$ down to $130 \mathrm{~m})$ from both soil profiles, but avoiding the boundaries between soil horizons. In total 28 samples were analyzed. Additionally, 11 samples from topsoil horizons were analyzed for organic carbon content, to characterize its spatial variability in the surface layers across the study site. Organic carbon content in all soil samples was determined using $\mathrm{K}_{2} \mathrm{Cr}_{2} \mathrm{O}_{7}$ wet-combustion method $[27,28]$ and then recalculated to concentrations of soil organic matter [28].

Particle size analysis was performed for the fine earth fraction $<1 \mathrm{~mm}$. The boundaries between six particle size classes were defined in accordance with the Russian conventional fraction groups [27]. The coarse and medium sand fraction $(1-0.25 \mathrm{~mm})$ and the fine sand fraction $(0.25-0.05 \mathrm{~mm})$ were separated by sieving while more fine-grained fractions of the coarse, medium and fine silt $(0.05-0.01 \mathrm{~mm} ; 0.01-0.005 \mathrm{~mm}$; and $0.005-0.001 \mathrm{~mm}$, respectively) as well as the clay fraction $(<0.001 \mathrm{~mm})$ were determined by the pipette method after sample pretreatment with sodium pyrophosphate. The data on textural fraction contents were used for the reconstruction of the particle size distributions $[29,30]$ and textural classes were approximated according to the FAO Guidelines for soil description [25]. Calcium carbonate contents and $\mathrm{pH}$ in a water suspension (soil:water ratio $=1: 2.5$ ), exchangeable cations and exchangeable acidity were analyzed using conventional methods for soils of forest zone [27].

Organic carbon in humus fractions (active and passive fulvic and humic acids) was determined according to Ponomareva and Plotnikova procedure [31]. Carbon and nitrogen concentrations for the C:N ratio were obtained using Vario EL III elemental analyzer (Elementar Analysensysteme $\mathrm{GmbH}$, Langenselbold, Germany). The elemental analysis was performed using the X-ray fluorescence spectrometry method after loss on ignition determination $\left(1000{ }^{\circ} \mathrm{C}\right)$ using the Philips PW2400 Sequential WXRF Spectrometer (Malvern Panalytical, Almelo, The Netherlands), with borate fusion applied in sample preparation for XRF analysis. Dithionite and oxalate extractable fractions of iron and aluminum were determined according to Mehra and Jackson [32], using a Cary 60 Spectrophotometer (Agilent Technologies, Santa Clara, CA, USA).

Analyses of extractible microbiomorphs included the determination of organic (spores and pollen, plant detritus, charcoal) and inorganic (phytoliths; spicules of sponge species) particles. Samples for the spore-and-pollen analysis were collected from the upper $0-5 \mathrm{~cm}$ of both soils. In the buried soil, two sides of the soil pit (western and northern), including the upper layer of the grave material, were sampled. For the analysis of phytoliths, replicate samples were taken from the upper $0-2 \mathrm{~cm}$ of the surface soil and also from the upper part of the grave fill, as well as from the two surface layers $(0-3 \mathrm{~cm}$ and $3-7 \mathrm{~cm})$ of the buried soil on both sides of the soil pit. To analyze the microbiomorphs, soil samples were treated in a multi-stage procedure [33-36]. In sample preparation for the phytolith analysis, fifty-gram soil samples were treated with a $30 \%$ solution of hydrogen peroxide, and then separated from quartz and other mineral grains by flotation in a heavy liquid with a density of $2.3 \mathrm{~g} \cdot \mathrm{mL}^{-1}$. Determination of phytoliths was carried out using an optical microscope at magnifications $200-900 \times$. For the study of palynological assemblages, samples were treated with $10 \% \mathrm{HCl}$ and sodium pyrophosphate, centrifuged in heavy liquid $\left(\mathrm{CdI}_{2}+\mathrm{KI}\right)$, and subjected to standard acetolysis. 
In order to determine pollen concentrations, Lycopodium spores were added to the recovered samples. Determination of pollen and spores was carried out using a light microscope at magnifications $400 \times$ and $1000 \times$. All pollen grains were counted in the recovered sample. Pollen identification was performed based on a reference collection using keys and illustrations by Moore et al. [37] and Beug [38]. Percentages of pollen groups were calculated from total pollen amount; percentages of spores were calculated referring to the total amount of pollen and spores.

Since wood or charcoal particles were not found, radiocarbon dating was carried out on humic acids extracted from the dark-colored grave fill material. The radiocarbon date was obtained by liquid scintillation counting (LSC) at the Laboratory of Isotope Research at the Herzen State Pedagogical University of Russia, St. Petersburg (marked by the SPb index). The quoted uncalibrated date was calculated as radiocarbon years before 1950 (years BP) using the $14 \mathrm{C}$ half-life of 5568 years. The error is quoted as one standard deviation and reflects both statistical and analytical errors. Measuring extracted humic acids does not yield absolute ages $[17,39]$ so the obtained radiocarbon date was not calibrated.

The elemental data treatment included the calculation of the molar ratios of immobile elements - $\mathrm{Ti}, \mathrm{Nb}$ and $\mathrm{Zr}$ - which was used to evaluate the parent material uniformity [40]. The amount of loss and gain, relative to the deepest parent material stratum, was quantitatively assessed using the eluvial/illuvial coefficient, or EIC [41]:

$$
\operatorname{EIC}(\%)=[(\mathrm{Xh} / \mathrm{Ih}) /(\mathrm{Xr} / \mathrm{Ir})-1] \times 100 \%,
$$

where $\mathrm{Xh}$ and $\mathrm{Xr}$ are the contents of element $\mathrm{X}$, while Ih and Ir are the contents of an immobile element (Ti) in soil horizons and parent rocks, respectively. A positive EIC value means that the element has been enriched in the soil horizon, relative to the parent material and a negative value suggests the loss of the element.

\section{Results}

\subsection{Soil Morphology}

The surface soil with Ah-AhB-Bw-C1-C2-C3-R horizons (Figure 3) represents a Folic Eutric Cambisol. The soil is formed on an upland slope with a gradient less than $5^{\circ}$ under broadleaf forest dominated by Acer platanoides and Quercus robur and admixture of Tilia cordata and Ulmus laevis. Parent material consists of loamy sand or sandy loam deposits underlain by unaltered calcareous sandstone slab at a depth of $130 \mathrm{~cm}$ (horizon R).

The upper part of the soil profile consists of a very dark brown (10 YR 2/2) Ah horizon with moderate granular structure and loam texture grading into the transitional mottled dark brown $\mathrm{AhB}$ horizon (Figure 3a, Table 1). 

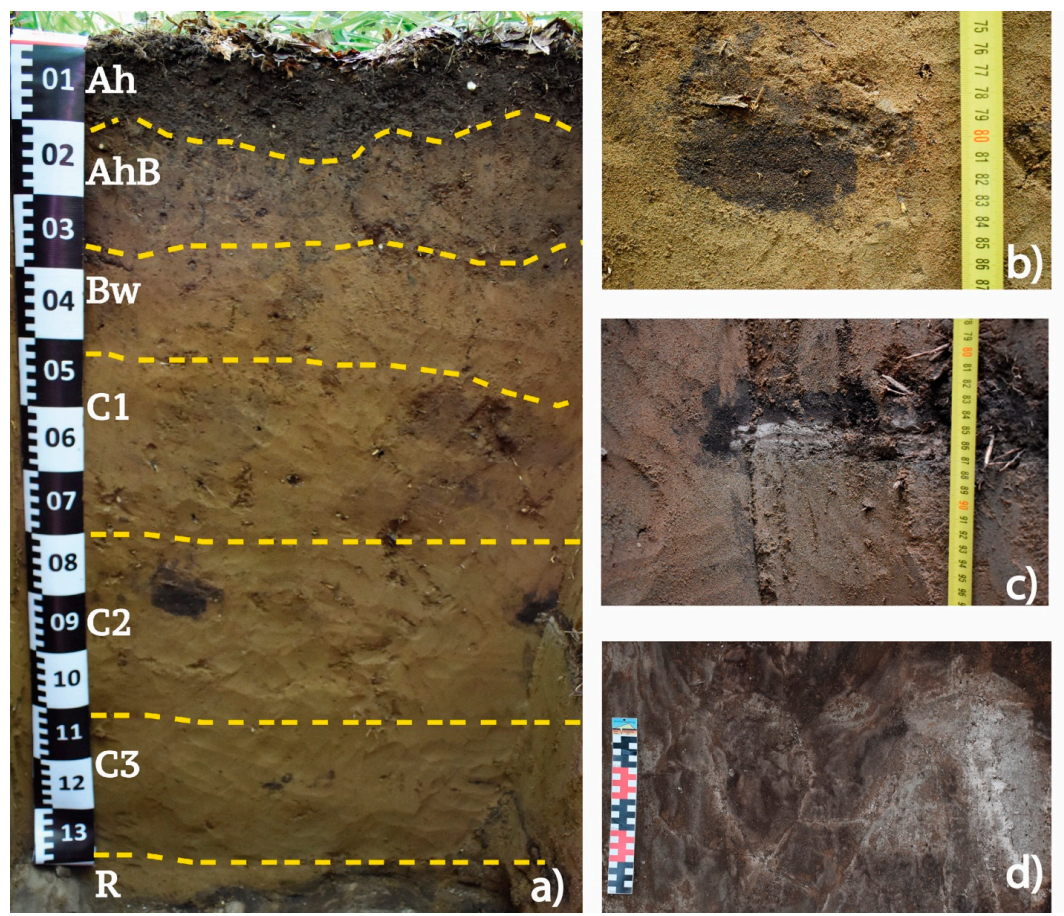

Figure 3. The surface soil (Folic Eutric Cambisol). (a) general view of the surface soil profile; (b) strongly weathered sandstone fragment that appear as very dark large spot in the C2 horizon; (c) weathered sandstone fragment with accumulation of dark-colored compounds translocated from the upper soil horizons; (d) consolidated calcareous sandstone plate (the view of from above, note dark coatings on the whitish surface of the unaltered sandstone).

The thickness of the Ah horizon varies between 7 and $12 \mathrm{~cm}$ (up to $16 \mathrm{~cm}$ in the surrounding soils). Below the AhB, there is a relatively thick $(16-20 \mathrm{~cm}) \mathrm{Bw}$ horizon with sandy clay texture situated above the parent material. Unlike the C horizon, the Bw horizon has a reddish color (5YR 4/4), is weakly structured and contains diffuse dark brown humus mottles (Table 1). The reddish shade is thought to have formed due to weathering or transformation of primary minerals producing ferric oxide and hydroxide coatings. At the depth of $42-48 \mathrm{~cm}$ the $\mathrm{C}$ horizons begins, distinguishing three sub-horizons. The yellowish C1 and C2 sub-horizons are of sandy loam or loamy sand texture and contain weakly to moderately weathered fragments of sandstone (up to $10 \mathrm{~cm}$ in diameter), typically covered by a distinct layer of very dark to almost black material (Figure 3c), while more strongly weathered sandstone fragments (large or fine) appear as very dark mottles (Figure 3b). The dark color of the material implies the presence of organic compounds and/or manganese oxides. The lowermost residuum, or the C3 horizon, which lies above the consolidated calcareous sandstone plate, is similar in texture to the $\mathrm{C} 1$ and C2 sub-horizons and also contains small dark mottles, but of a reduced matrix characterized by greenish colors typical for redox depletion. Below, the surface of the unaltered calcareous sandstone slab in the $\mathrm{R}$ horizon displays continuous coatings (Figure 3d) consisting of dark material similar to that found in the residuum horizons. 
Table 1. Field description of the studied soils.

\begin{tabular}{|c|c|c|c|c|c|c|c|c|c|}
\hline Horizon & $\begin{array}{c}\text { Lower } \\
\text { Boundary, } \mathrm{cm}\end{array}$ & $\begin{array}{l}\text { Colour of General } \\
\text { Matrix (Moist) }\end{array}$ & Mottling & $\begin{array}{c}\text { Rock } \\
\text { Fragments }\end{array}$ & Structure & $\begin{array}{l}\text { Carbonate } \\
\text { Reaction }\end{array}$ & $\begin{array}{l}\text { Abundance } \\
\text { of Roots }\end{array}$ & $\begin{array}{c}\text { Horizon Boundary } \\
\text { Topography/Distinctness }\end{array}$ & $\begin{array}{l}\text { Consistency } \\
\text { When Moist }\end{array}$ \\
\hline \multicolumn{10}{|c|}{ Surface Soil—Folic Eutric Cambisol } \\
\hline $\mathrm{Ah}$ & $7(10)$ & 10 YR $2 / 2$ & - & $\mathrm{N}$ & MOSBGR & $\mathrm{N}$ & C & $\mathrm{W} / \mathrm{C}$ & FR to FI \\
\hline AhB & $26(28)$ & $10 \mathrm{YR} 3 / 3$ & - & $\mathrm{N}$ & $\mathrm{WMSB}+\mathrm{AB}$ & $\mathrm{N}$ & $\mathrm{C}$ & $\mathrm{W} / \mathrm{C}$ & FR \\
\hline Bw & $42(48)$ & $5 Y R 4 / 4$ & $\mathrm{~F}$ & $\mathrm{~N}$ & WESBAS & $\mathrm{N}$ & $\mathrm{F}$ & $\mathrm{I} / \mathrm{C}$ & FR \\
\hline $\mathrm{C} 1$ & 70 & 7.5 YR $4 / 4$ & $\mathrm{~V}$ & $\mathrm{~N}$ & WEAS+LU & $\mathrm{N}$ & $\mathrm{F}$ & $\mathrm{W} / \mathrm{G}$ & FR to VFR \\
\hline $\mathrm{C} 2$ & 102 & 10 YR 4/3 & - & C-M & WE & $\mathrm{N}$ & $\mathrm{F}$ & $\mathrm{W} / \mathrm{C}$ & FR to VFR \\
\hline C3 & 130 & 10 YR 4/4 & - & V-F & WE & $\mathrm{N}$ & $\mathrm{F}$ & $\mathrm{A} / \mathrm{S}$ & VFR to LO \\
\hline $\mathrm{R}$ & $\ldots$ & 10 YR 3/2-4 & - & $\mathrm{N}$ & - & EX & - & - & - \\
\hline \multicolumn{10}{|c|}{ Buried Soil—Folic Eutric Cambisol (Protocalcic) } \\
\hline Ahb & $9(14)$ & 7.5 YR 2.5/1-2 & - & F-F & WE & SL & $\mathrm{F}$ & $\mathrm{W} / \mathrm{C}$ & FR to FI \\
\hline $\mathrm{AhBb}$ & $18(26)$ & 7.5 YR $2.5 / 2-3$ & - & F-F & WE & $\mathrm{N}$ & $\mathrm{F}$ & $\mathrm{W} / \mathrm{C}$ & FR to FI \\
\hline Bwb & $31(39)$ & 7.5 YR $3 / 3$ & - & F-F & WE & $\mathrm{N}$ & $\mathrm{F}$ & $\mathrm{W} / \mathrm{G}$ & FR to FI \\
\hline $\mathrm{BCb}$ & $45(50)$ & $10 \mathrm{YR} 3 / 4$ & - & $\mathrm{N}$ & WE & $\mathrm{N}$ & $\mathrm{N}$ & $\mathrm{W} / \mathrm{G}$ & FR \\
\hline $\mathrm{Cb}$ & 100 & 10 YR 3/4 & - & $\mathrm{N}$ & WE & $\mathrm{N}$ & $\mathrm{N}$ & $\mathrm{W} / \mathrm{G}$ & VFR \\
\hline $\mathrm{Ckb}$ & 135 & 10 YR 3/6 & - & $\mathrm{N}$ & WE & SL & $\mathrm{N}$ & S/A & VFR to LO \\
\hline $\mathrm{R}$ & $\ldots$ & & - & $\mathrm{N}$ & - & EX & - & - & - \\
\hline
\end{tabular}

Mottling: Abundance: V-very few, F-few. Rock fragments: Abundance: N-none, V-very few (0-2\%), F-few (2-5\%), C-common (5-15\%); Size: F-fine gravel (2-6 mm),

M-medium gravel $(6-20 \mathrm{~mm})$. Structure: grades: WE-wWeak, MO—-moderate; Types: AB-angular blocky, GR—granular, SB-subangular blocky, AS—angular and subangular blocky,

LU—lumpy. Carbonate reaction: $\mathrm{N}-$ non-calcareous, SL-slightly calcareous, EX-extremely calcareous. Abundance of roots: $\mathrm{F}-\mathrm{few}, \mathrm{C}-\mathrm{common}, \mathrm{N}-$ none. Horizon boundary:

Topography: S—smooth, W—-wavy, I—irregular; Distinctness: A—abrupt, C—clear, G—gradual; Consistency when moist: LO-loose, VFR-very friable, FR—friable, FI-firm. 
The kurgan mound is covered by the same type of forest as the surface soil. The soil developed in the upper part of the ancient construction, approximately 4000 years old, is a weakly differentiated Folic Umbrisol with Ah-AhC1-AhC2 horizons. It is underlain by well-stratified layers R1 and R2 which overlie the buried soil (Figure 4a). The upper limit of the buried soil is located $165 \mathrm{~cm}$ below the present-day surface of the kurgan, marked by a $2-5 \mathrm{~cm}$ thick pale brown layer separating the buried soil from the mound. Due to the presence of this layer, the buried soil was identified in two walls of the excavation-western and northern (Figure 4a). Like the surface soil, the buried soil is limited in depth by continuous consolidated calcareous sandstone slab, starting a $130 \mathrm{~cm}$ below the upper limit of the buried soil, coinciding with the hard rock position in the surface soil. The buried soil in the northern wall was partially disturbed by anthropogenic activities, ancient ones related to the construction of the grave, and more recent ones associated with the excavation by archeologists in 1927, so the total width of the undisturbed buried soil in the northern wall is slightly less $(80 \mathrm{~cm})$ than in the western one $(125 \mathrm{~cm})$.
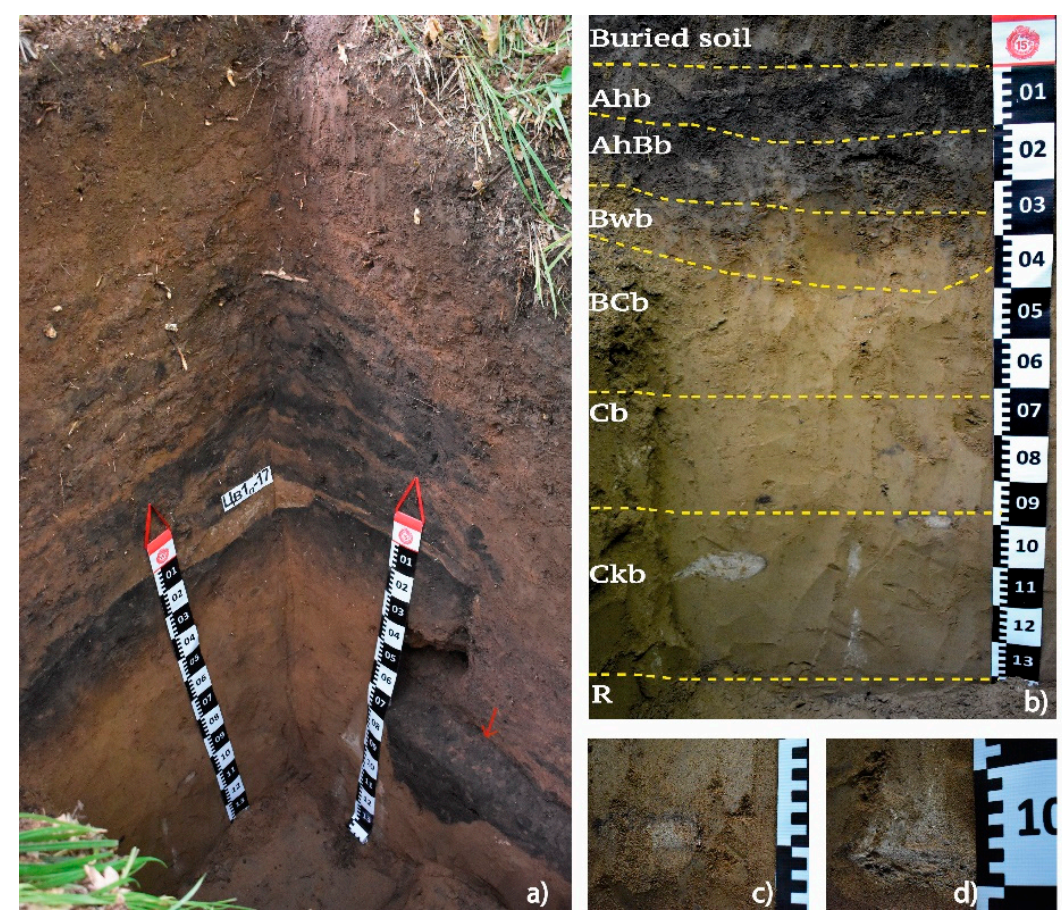

Figure 4. The general view of the pit (295 cm deep) made in the kurgan during the field research (a) and the profile of the buried soil (b-d). (a) the stratified mound material and the buried soil (Folic Eutric Cambisol Protocalcic) exposed in the western (left) and northern (right) walls. Note $2-5 \mathrm{~cm}$ thick pale brown layer separating the buried soil from the mound and the grave filled with black earth on the northern wall (indicated by red arrow); (b) general view of the buried soil profile; (c,d) altered calcareous coarse sandstone fragments in Ckb horizon.

The buried soil was identified as Folic Eutric Cambisol Protocalcic. The following sequence of the horizons was distinguished: Ahb-AhBb-Bwb-BCb-Cb-Ckb-R (Figure 4a, Table 1). The whole soil profile is weakly structured. The upper Ahb horizon has a very dark color-black to very dark brown, 7.5 YR 2.5/1-2, which is darker than the humus horizon of the surface soil, although the thicknesses of these horizons are almost equal. The transitional horizon AhBb displays a sandy clay loam texture, the presence of humus mottles and weak horizontal lamination, derived from the original layering observed in the sedimentary hard rock. The underlying Bwb horizon has a similar sandy clay loam texture and also shows weak signs of horizontal structuring. This horizon contains very fine fragments of lithogenic material (calcareous and non-calcareous) and shows traces of past mesofauna activity. Below the Bwb, the soil stratum consists of unstructured sandy loam. The $\mathrm{BCb}$ 
horizon has a yellowish-brown color, grading into the $\mathrm{Cb}$ horizon which contains fine soft $\mathrm{Mn}$ nodules, further underlain by a slightly reduced loamy sand $\mathrm{Ckb}$ horizon with numerous altered calcareous coarse sandstone fragments (Figure $4 \mathrm{~b}-\mathrm{d}$ ) and finely divided lithogenic material which causes a slight effervescence of the soil matrix.

\subsection{Soil Micromorphology}

The study of thin sections confirms that both soils are formed in parent material derived from the weathering of well-cemented sandstone, which consist of sand grains conjoined by carbonate fine material (Figure 5A). The coarse material pattern in the cemented sandstone shows the tendency to subhorizontal bedding (long axes are subhorizontal) and all mineral grains are covered by very thin Fe-coatings (Figure 5A,B) originated probably from weathering of primary minerals. The weathering of the sandstone produced loose loamy sands with a predominance of sand size grains, $120-170 \mu \mathrm{m}$ in diameter. Most of the coarse grains are only slightly rounded and retain their shape, some of the grains shows signs of weathering, e.g., cracks. The mineral composition of the coarse fraction does not change significantly along the soil profiles: it consists of quartz (70\%), feldspar (15\%) and other opaque minerals with high Fe-content (Figure 5B). Fragments of altered sandstone are well preserved in the lower parts of both profiles: in the surface soil at $95 \mathrm{~cm}$ and deeper, in the buried soil at $110 \mathrm{~cm}$ and deeper (Figure 5C). In the inner (consolidated) parts of the fragments and in their outer parts (with loose groundmass) a subhorizontal bedding of coarse grains inherited from the hard rock are observed. This bedding can be traced in the profiles of the buried and surface soils up to the depth of $\sim 80 \mathrm{~cm}$.

There are different forms of carbonates-primary (geogenic) and secondary (pedogenic). In the surface soil, the nodules of primary carbonates with blurred boundary are found between $90-130 \mathrm{~cm}$, derived from the altered fragments described above (Figure 5E). The buried soil contains mainly primary carbonates, but also secondary carbonates are found, present as (a) large (up to $1.5 \mathrm{~cm}$ thick) micrite nodules inside the groundmass, (b) coatings on the wall of weakly developed voids (Figure 5F). The latter tend to have the shape of root caps.

In addition to differences in carbonate forms, the buried and the surface soils can be differentiated by other pedofeatures, including microstructure, type and distribution of fine material. The microstructure of the upper layer in the buried soil is compacted by diagenesis, and is very bioturbated ( $\sim 40 \%$ of the thin section area is formed by passage infillings). Nevertheless, there are signs of moderately separated granular microstructure (Figure 6A). In the Ah horizon of the surface soil the microstructure is highly separated only in the uppermost $5 \mathrm{~cm}$, while the rest of the horizon displays a weakly separated angular blocky microstructure. (Figure 6B). In the subjacent strata the microstructure shows similar features in both soils, being close to massive.

The surface layers of the two soils also differ in the types of fine material. In the buried soil, the surface layer contains very dark brown (mull type) humus, very well developed, consisting of visible dark clustered particles (Figure 6A,C) indicating its formation in a productive ecosystem. In the surface soil, the fine material contains brown (moder type) humus, including a high amount of small single dark particles and plant residues in various stages of decomposition (Figure 6B,D). 

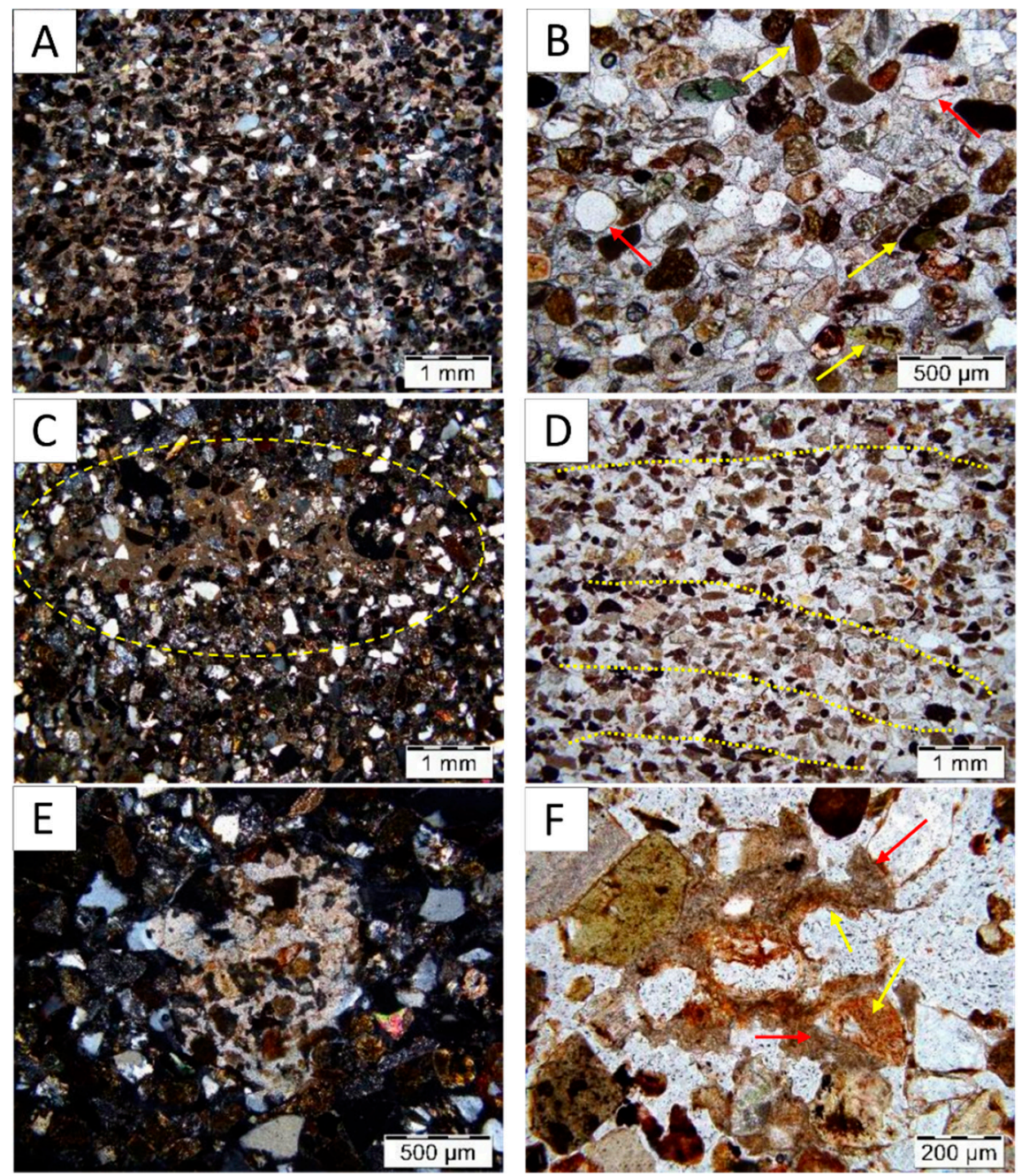

Figure 5. Microfeatures of the groundmass in the surface soil (A-C) and in the buried soil (D-F). (A,B) Microphotographs of the C3 horizon of the surface soil at depth 125-130 cm: calcareous well-cemented sandstone slab, NX (A); mineral composition of the sandstone slab, NII (B). Please note: the non-opaque sand-grains (marked by yellow arrows), thin coatings on the mineral grains (marked by red arrows). (C) Microphotograph of the C2 horizon of the surface soil at depth $95 \mathrm{~cm}$ : fragments of weathered calcareous sandstone slab, incorporated in the non-calcareous groundmass; NX. (D,E) Microphotographs of the Ckb horizon of the buried soil at depth $110-115 \mathrm{~cm}$ : composition of the parent material with the tendency of sand grains to lamination NII (D), weathered primary carbonates; NX (E,F) Microphotograph of the $\mathrm{Cb}$ horizon of the buried soil at depth 60-65 cm: secondary carbonate nodules (marked by red arrows). Please also note the residuals of modern roots in the inner part (marked by yellow arrows). 


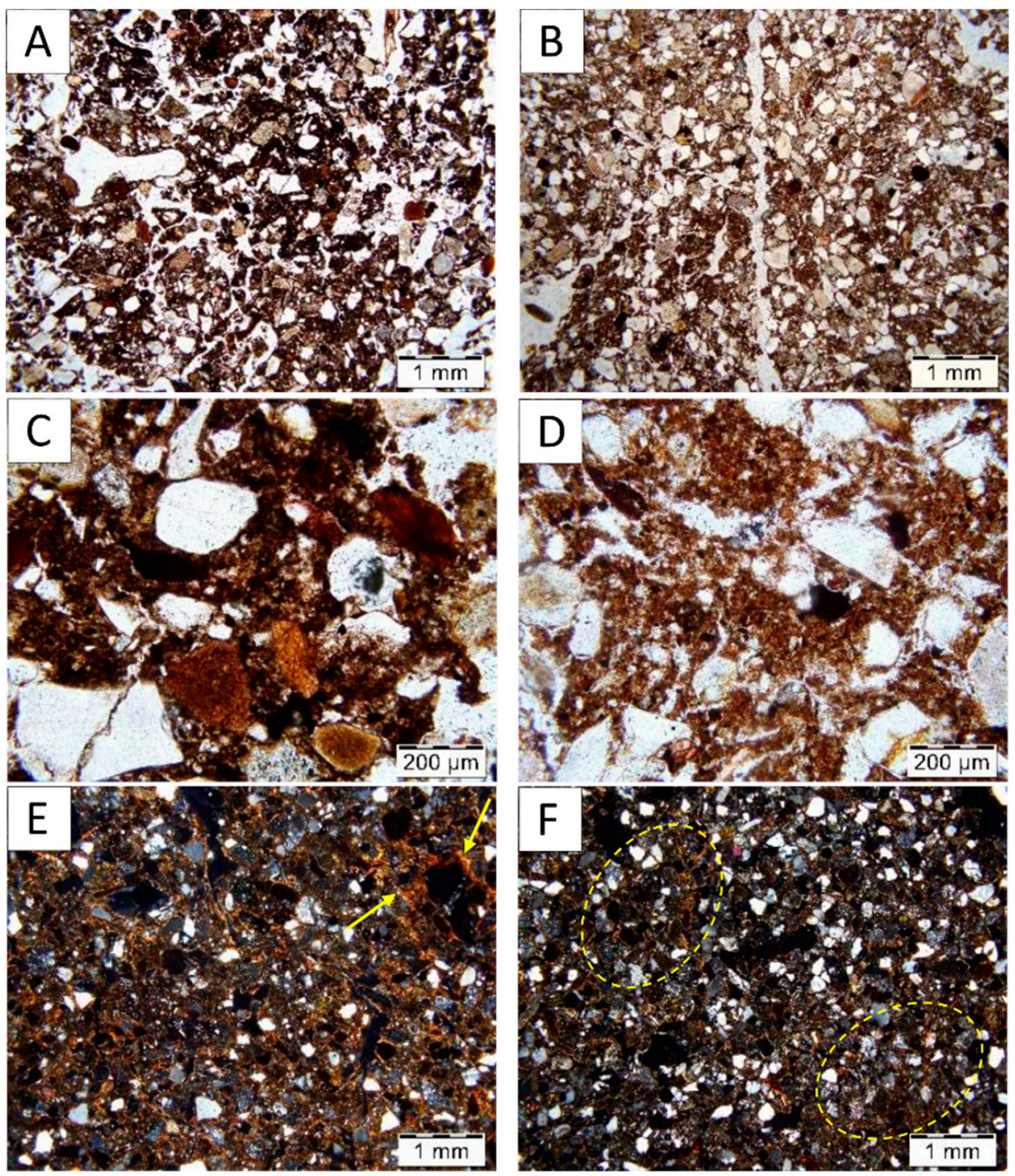

Figure 6. Microstructure and fine material features in the buried soil (left- $\mathbf{A}, \mathbf{C}, \mathbf{E})$ and in the surface soil (right-B,D,F). (A,B) Microphotographs of the Ahb horizon $(0-5 \mathrm{~cm})$ of the buried soil with moderately separated granular microstructure (A) and the Ah horizon $(3-8 \mathrm{~cm})$ of the surface soil with weakly separated angular blocky microstructure (B); please note the difference in the color of the fine material; NII. (C,D) Microphotographs of the Ahb horizon $(0-5 \mathrm{~cm})$ of the buried soil with dark brown cluster-like fine material (C) and the Ah horizon $(3-8 \mathrm{~cm})$ of the surface soil (D) with brown fine material including small single dark particles and plant residues; NII. (E,F) Microphotographs of subsurface horizons. The Bwb horizon $(20-25 \mathrm{~cm}$ ) of the buried soil (E): fine material with high birefringence and poro-, granostriated b-fabric; please note thin clay coatings (marked by yellow arrows). The Bw horizon $(30-35 \mathrm{~cm}$ ) of the surface soil: scarce fine material and single spaced equal enaulic $\mathrm{c} / \mathrm{f}$ related distribution; please note zones similar to the Bwb horizon groundmass (marked by dashed yellow ellipses); NX.

The studied soils showed also differences in the fine material distribution. In the buried soil, material with a close porphyric c/f related distribution [26] was determined in the Bwb horizon. The fine material observed in this horizon is characterized by a high birefringence with poro- and granostriated b-fabric marked by thin clay coatings. Thicker clay coatings occur on the surface of rare void walls. (Figure 6E). Small incorporated fragments of the Bwb horizon are found in the groundmass even below the Bwb horizon, at depth of $45 \mathrm{~cm}$. In the surface soil, the soil groundmass at the same depth is characterized by single spaced equal enaulic $\mathrm{c} / \mathrm{f}$ related distribution (braces of fine material 
link the coarse grains). It has much less birefringence of the fine material with granostriated b-fabric. Thus, we cannot classify this material as Argic, although zones with micromorphological features similar to the buried soil still can be found (Figure 6F).

The amount of the fine material is decreasing with depth. In the upper $20 \mathrm{~cm}$ single spaced porphyric c/f-related distribution is described in both soils, but the amount of fine material is higher in the Ahb horizon relative to the Ah horizon. In the 30-50 cm layer, different types of equal enaulic c/f-related distribution are found. Convex gefuric distribution starts in the buried soil at depth of $70 \mathrm{~cm}$ and in the surface soil at depth of $85 \mathrm{~cm}$. In the surface soil, the fine material itself is more ferriferous than in the buried soil where it includes more clay. In both soils, two types of materials can be seen at the depth of 100-105 cm: zones where coarse grains are completely uncoated (Figure 7A) and zones where coarse grains are linked by ferriferous bridges (Figure 7B). This may be caused by the stagnation of water and gleyzation at the boundary with unaltered sandstone plate.
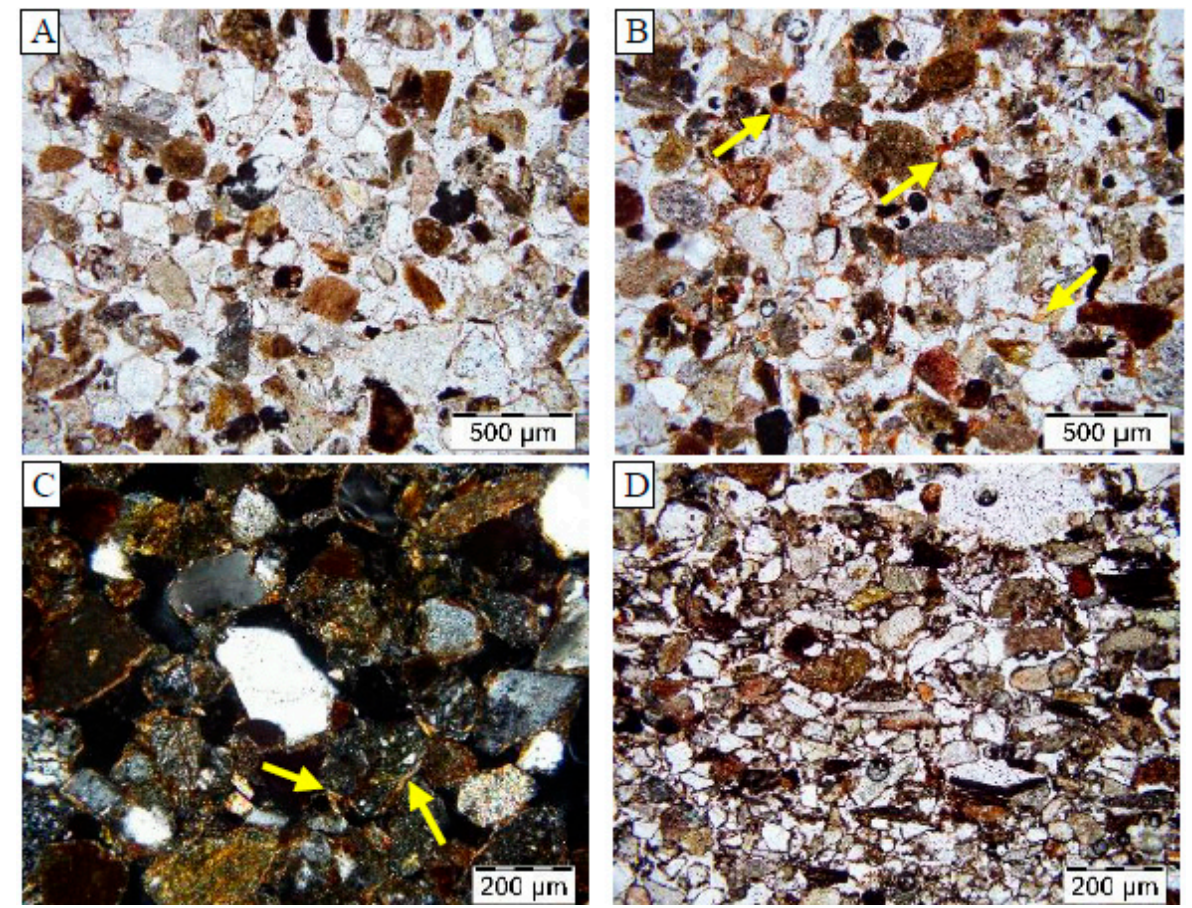

Figure 7. Pedofeatures of the $C$ horizons in the surface soil. (A,B) Microphotographs of $C 2$ horizon $(110-115 \mathrm{~cm})$. (A) the zone of coarse monic c/f-related distribution and (B) the zone of concave gefuric $\mathrm{c} / \mathrm{f}$-related distribution; note the red-brown colored links between the sand grains (marked by yellow arrows); NII. (C) Microphotograph of the C1 horizon $(60-65 \mathrm{~cm}$ ) with stagnic features, please note bleached clay coatings (marked by yellow arrows); NX. (D) Microphotograph of the R horizon (130-132 cm); note the enrichment in dark fine material in comparison to the microphotograph A; NII.

The gleyzation features are also seen in the lower part of the $C 2$ horizon where thin bleached clay coatings cover coarse grains (Figure 7C); other zones are enriched in ferriferous material, while no iron nodules or concretions are found. At the boundary with the sandstone bedrock there is a zone, 2-4 cm thick, where translocated organic and mobile Mn-Fe compounds were accumulated. As a result, the sand grains are covered by thick dark coatings composed mainly of organic matter (Figure 7D).

\subsection{Radiocarbon Date}

In the light of the radiocarbon dating of the organic (humic) substances which were separated from the grave fill material the paleosol was buried not earlier than $4425+/-50$ yrs. BP, SPb 2455 , or the beginning (the first half) of the Subboreal period, which confirms the archeological dating of the kurgans [18]. 


\subsection{Analytical Features}

Soil granulometry. Both soils are dominated by sand particles (Figure 8), in particular by the fine and very fine sand fractions $(0.25-0.05 \mathrm{~mm})$, although both profiles contain sufficient amounts of clay and silt to classify the texture of the two soils as sandy clay loam or sandy loam up to the depth of $80-90 \mathrm{~cm}$. The total sand content in both soils is lower in the topsoil horizons compared to the deeper strata, reaching its maximum values of $80-85 \%$ in the residuum, classified as having a loamy sand texture. In the surface soil the changes in the vertical distribution of the total sand content are rather smooth compared to those in buried soil, in which a notable increase of the coarser fractions is observed in the $\mathrm{BCb}$ horizon (Figure 8).

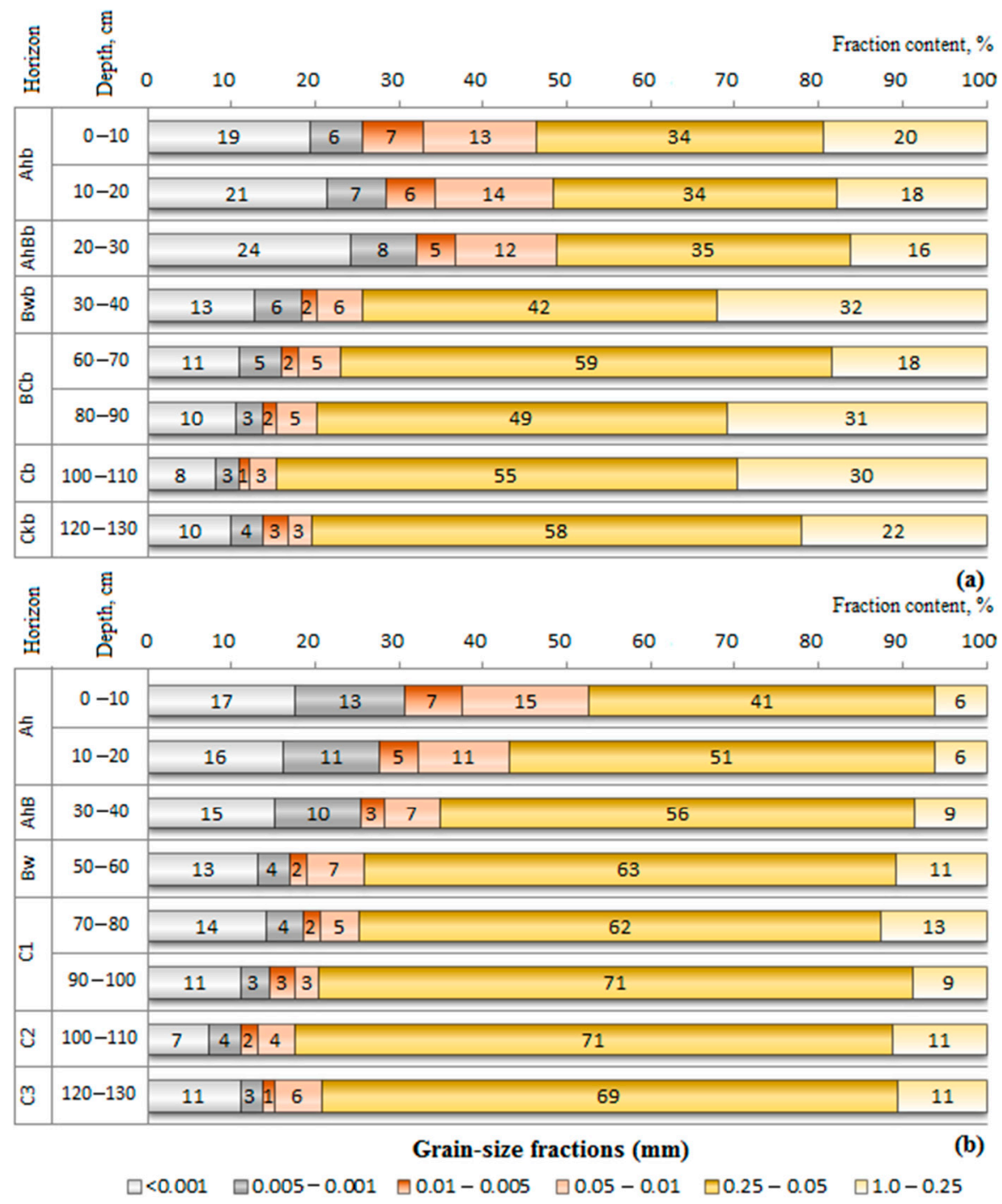

Figure 8. The granulometry of the surface soil (a) and the buried soil (b).

The clay contents vary between 24 and $8 \%$ in the buried soil, compared to 17.5 and $7 \%$ in the surface soil, showing higher values in the upper parts of the two soils (Figure 8). In the surface soil the clay distribution curve displays a smooth decrease to the $C$ horizons, with no notable enrichment in the Bw horizon, while in the buried soil a visible peak in the clay content is noted in the $\mathrm{Bw}$ horizon (Figure 8). However, the ratio of the clay content in the Bw horizon to the AhB horizon is 1.1 , which qualifies as a very weak textural change [23,42]. The contribution of the silt fractions, in particular of coarse silt particles $(0.05-0.01 \mathrm{~mm})$, is relatively small compared to the amount of silt in the loess-derived soils widespread in the middle Volga region. Similarly to clay, the silt enriches the 
upper soil horizons, up to $30 \mathrm{~cm}$ in the buried soil and to $40 \mathrm{~cm}$ in the surface soil, with their lowest content observed in the $\mathrm{Cb}$ and $\mathrm{C}$ horizons.

Selected chemical data (Table 2). The Ah, AhB, Bw and $\mathrm{C} 1$ horizons of the surface soil are slightly acidic up to the depth of $70 \mathrm{~cm}$, while the $\mathrm{C} 2$ and $\mathrm{C} 3$ horizons are neutral.

Table 2. Selected chemical features in the surface soil and buried soil.

\begin{tabular}{|c|c|c|c|c|c|c|c|c|c|c|}
\hline \multirow{2}{*}{ Horizon } & \multirow{2}{*}{ Depth, cm } & \multirow{2}{*}{$\mathrm{pH}$} & \multirow{2}{*}{ SOM, \% } & \multicolumn{3}{|c|}{ Exchangeable Cations, $\mathrm{cmol}_{\mathrm{c}} \mathrm{kg}^{-1}$} & \multicolumn{3}{|c|}{ Exch. Acidity, $\mathrm{cmol}_{\mathrm{c}} \mathrm{kg}^{-1}$} & \multirow{2}{*}{$\mathrm{CaCO}_{3}, \%$} \\
\hline & & & & $\mathrm{Ca}^{2+}$ & $\mathrm{Mg}^{2+}$ & $\mathrm{K}^{+}$ & $\mathrm{Na}^{+}$ & $\mathrm{H}^{+}$ & $\mathrm{Al}^{3+}$ & \\
\hline \multicolumn{11}{|c|}{ Surface Soil-Folic Eutric Cambisol } \\
\hline Ah & $0-10$ & 6.36 & 4.8 & 29.4 & 3.6 & 0.7 & 0.02 & 0.01 & 0.02 & - \\
\hline \multirow{2}{*}{ AhB } & $10-20$ & 5.95 & 1.59 & 18.3 & 2.6 & 0.1 & 0.0 & 0.03 & 0.20 & - \\
\hline & $20-30$ & 5.91 & 0.81 & & & & & & & - \\
\hline \multirow{2}{*}{ Bw } & $30-40$ & 6.22 & 0.6 & 24.1 & 3.2 & 0.1 & 0.1 & 0.01 & 0.37 & - \\
\hline & $40-50$ & 6.31 & 0.78 & & & & & & & - \\
\hline \multirow{2}{*}{$\mathrm{C} 1$} & $50-60$ & 6.26 & 1.15 & 22.6 & 2.8 & 0.1 & 0.0 & 0.01 & 0.27 & - \\
\hline & $60-70$ & 6.41 & 0.36 & & & & & & & - \\
\hline \multirow{4}{*}{$\mathrm{C} 2$} & $70-80$ & 6.52 & 0.31 & 22.4 & 2.9 & 0.1 & 0.1 & 0.01 & 0.12 & 0 \\
\hline & 80-90 & 6.66 & 0.39 & & & & & 0.01 & 0.12 & 0 \\
\hline & $80-87$ mottle $^{1}$ & 6.81 & 2.03 & 20.6 & 2.4 & 0.1 & 0.1 & 0.00 & 0.03 & 0.42 \\
\hline & 90-100 & 6.59 & 1.2 & 23.1 & 2.9 & 0.1 & 0.1 & 0.00 & 0.08 & 0.02 \\
\hline \multirow{3}{*}{$\mathrm{C} 3$} & $100-110$ & 6.76 & 0.26 & & & & & 0.00 & 0.08 & 0 \\
\hline & $110-120$ & 6.87 & 0.16 & 22.2 & 2.4 & 0.1 & 0.1 & 0.00 & 0.03 & 0.02 \\
\hline & $120-130$ & 7.13 & 0.1 & 22.5 & 2.2 & 0.1 & 0.1 & 0.01 & 0.02 & 0.02 \\
\hline & \multicolumn{10}{|c|}{ Buried Soil-Folic Eutric Cambisol (Protocalcic) } \\
\hline Ahb & $0-10$ & 8.12 & 2.52 & 30.8 & 4.4 & 0.3 & 0.2 & - & & 0.15 \\
\hline \multirow{2}{*}{$\mathrm{AhBb}$} & $10-20$ & 8.27 & 1.47 & 28.2 & 4.5 & 0.3 & 0.2 & - & & 0.15 \\
\hline & $20-25$ & 8.17 & 0.44 & 28.8 & 4.7 & 0.3 & 0.3 & - & & 0.15 \\
\hline Bwb & $25-30$ & 8.13 & 0.21 & & & & & - & & 0.15 \\
\hline \multirow{3}{*}{$\mathbf{B C b}$} & $30-40$ & 8.40 & 0.16 & & & & & - & & 0.15 \\
\hline & $40-50$ & 8.32 & 0 & 22.8 & 3.7 & 0.1 & 0.2 & - & & 0.15 \\
\hline & $50-60$ & 8.29 & 0.28 & & & & & - & & 0.15 \\
\hline \multirow{3}{*}{$\mathrm{Cb}$} & $60-70$ & 8.50 & 0.51 & 27.9 & 3.6 & 0.1 & 0.2 & - & & 0.07 \\
\hline & $70-80$ & 8.32 & 0.47 & & & & & - & & 0.07 \\
\hline & $80-90$ & 8.32 & 0.08 & 22.3 & 3.1 & 0.1 & 0.2 & - & & 0.07 \\
\hline \multirow{4}{*}{ Ckb } & 90-100 & 8.32 & 0.89 & & & & & - & & 0.07 \\
\hline & $100-110$ & 8.43 & 0.3 & 21.6 & 2.7 & 0.1 & 0.1 & - & & 0.07 \\
\hline & $110-120$ & 8.51 & 0.37 & & & & & - & & 0.02 \\
\hline & $120-130$ & 8.71 & 0.24 & 44.7 & 2.6 & 0.1 & 0.1 & - & & 0.90 \\
\hline
\end{tabular}

${ }^{1}$ strongly weathered sandstone fragment that appears as a very dark large spot on the soil face.

Carbonates are leached from the profile of the surface soil except for the lower strata and large mottles where carbonates are still detectible (Table 2). In contrast, the buried soil shows moderately alkaline reactions in most of the horizons, with detectable levels of calcium carbonates $(0.02-0.15 \%)$ and strongly alkaline $\mathrm{pH}$ in the $\mathrm{Ckb}$ horizon having calcareous bedrock fragments.

The exchangeable ions in the two soils are represented almost entirely by bases: $\mathrm{Ca}^{2+}>>\mathrm{Mg}^{2+}>$ $\mathrm{Na}^{+}, \mathrm{K}^{+}$(Table 2). $\mathrm{Ca}^{2+}$ saturation varies between $85-94 \%$ in the buried soil and $86-90 \%$ in the surface soil. The acidic cations $\left(\mathrm{Al}^{3+}, \mathrm{H}^{+}\right)$occur in minor proportions $(0.1-1.4 \%)$ only in the surface soil.

Soil organic matter (SOM). The analysis of the 11 samples of the topsoil horizons collected around the kurgan mound showed that the SOM content in the surface soils varies between $4 \%$ and $11 \%$, with an average exceeding $6 \%$, which classifies the surface soils of the study site as strongly humic. The studied surface soil contains about $5 \%$ of organic matter in the Ah horizon (Table 2). The SOM content decreases first sharply to $1.5 \%$ at a depth of $10-20 \mathrm{~cm}$ and then more smoothly towards the lower part of the soil profile $(0.3 \%-0.1 \%)$, although showing irregular patterns and local peaks $(1-2 \%)$ at the depths $50-60 \mathrm{~cm}$ and $80-100 \mathrm{~cm}$ (Table 2). Compared to the surface soil, the SOM content of the buried soil is twice lower in its upper Ahb horizon, due to biomineralization after burying [13], while comparable amounts of SOM are found in the $\mathrm{C}$ horizons. As in the surface soil, the distribution of humus throughout the buried soil profile shows similar irregular patterns. The C:N ratio of topsoil 
ranges from 10:1 (in the buried soil) to 13:1 (in the surface soil), indicating that both soils contain humus of moder or mull type.

The fractionation of humus substances performed for the upper horizon of both soils revealed that in the surface soil the content of organic carbon in the separated fulvic and humic acids was nearly equal (Table 3), which is very typical of soils developed under broadleaf forest vegetation. In the buried soil, the ratio between carbon content in humic and fulvic acids was extremely wide: the level of $C$ in humic acids $\left(\mathrm{C}_{\mathrm{HA}}\right)$ was nearly 5 times higher than in fulvic acids $\left(\mathrm{C}_{\mathrm{FA}}\right)$. The further fractionation of the humic acids in the humus horizons implies that most of them in the buried soil were preserved as compounds associated with Ca carbonates (Table 3), while in the surface soil they were found both in association with Ca carbonates and sesquioxides.

Table 3. Characteristics of humus.

\begin{tabular}{|c|c|c|c|c|c|c|c|c|c|c|c|}
\hline TOC $^{3}, \%$ & \multicolumn{4}{|c|}{ Fractions of Humic Acids ${ }^{1} \mathrm{C}$ org Content, \% * } & \multicolumn{5}{|c|}{ Fractions of Fulvic Acids C org Content, \% } & Humins & $\mathrm{C}_{\mathrm{HA}} / \mathrm{C}_{\mathrm{FA}}{ }^{2}$ \\
\hline \multicolumn{12}{|c|}{ Surface Soil-Folic Eutric Cambisol } \\
\hline \multicolumn{12}{|c|}{ Buried Soil-Folic Eutric Cambisol (Protocalcic) } \\
\hline 1.46 & 0.05 & 0.33 & 0.15 & 0.53 & 0.00 & 0.02 & 0.03 & 0.07 & 0.11 & 0.82 & 4.80 \\
\hline
\end{tabular}

${ }^{1} \mathrm{HA} 1-$ free humic acids and associated with $\mathrm{R}_{2} \mathrm{O}_{3}, \mathrm{HA} 2$ - humic acids predominantly associated with calcium carbonates, $\mathrm{HA}$ - humic acids associated with $\mathrm{R}_{2} \mathrm{O}_{3}$ and clay minerals; FA1a-free fulvic acids and associated with mobile $\mathrm{R}_{2} \mathrm{O}_{3}$, FA1-fulvic acids associated with HA1 fraction, FA2-fulvic acids associated with HA2 fraction, FA3 - fulvic acids associated with HA3 fraction. ${ }^{2} \mathrm{C}_{\mathrm{HA}}$-carbon of humic acids; $\mathrm{C}_{\mathrm{FA}}$-carbon of fulvic acids. ${ }^{3}$ TOC-total organic carbon.

Elementary analysis. The data on major oxides and trace elements are presented in Table 4. Relative to decalcified loess deposits occurring in the Middle Volga region (Table 4) the sandstone residuum is more calcareous and has higher contents of $\mathrm{NaO}_{2}, \mathrm{Fe}_{2} \mathrm{O}_{3}$ (1.9-1.7 times), $\mathrm{MgO}$ (1.3-1.4 times), $\mathrm{P}_{2} \mathrm{O}_{3}$ and $\mathrm{CaO}$ (1.2-1.3 times higher) as well as higher levels of some trace elements associated with ferromagnesian minerals, such as $\mathrm{Cr}$ (4.7 times), $\mathrm{Ni}$ (3.2 times), $\mathrm{V}$ (1.4 times) and also $\mathrm{Sr}$ (1.5 times), present in calcareous material, while trace elements that occur in relatively stable minerals ( $\mathrm{Ti}, \mathrm{Zr}$, $\mathrm{Nb}, \mathrm{Y})$ or in clay $(\mathrm{Pb}, \mathrm{Rb})$ were found in lower amounts. 
Table 4. Total concentrations of major oxides, loss on ignition (LOI) \% and trace elements concentrations $\left(\mathrm{mg} \cdot \mathrm{kg}^{-1}\right)$.

\begin{tabular}{|c|c|c|c|c|c|c|c|c|c|c|c|c|c|c|c|c|c|c|c|c|c|c|c|}
\hline Horizon & Depth & $\mathrm{SiO}_{2}$ & $\mathrm{Al}_{2} \mathrm{O}_{3}$ & $\mathrm{Fe}_{2} \mathrm{O}_{3}$ & $\mathrm{Na}_{2} \mathrm{O}$ & $\mathrm{CaO}$ & $\mathrm{MgO}$ & $\mathrm{K}_{2} \mathrm{O}$ & $\mathrm{TiO}_{2}$ & $\mathrm{MnO}$ & $\mathrm{P}_{2} \mathrm{O}_{5}$ & LOI & Ва & $\mathrm{Cr}$ & $\mathrm{Zr}$ & $\mathrm{Sr}$ & V & $\mathrm{Ni}$ & $\mathrm{Zn}$ & $\mathbf{R b}$ & $\mathrm{Cu}$ & $\mathrm{Y}$ & $\mathrm{Nb}$ \\
\hline \multicolumn{24}{|c|}{ Surface Soil—Folic Eutric Cambisol } \\
\hline $\mathrm{Ah}$ & $0-10$ & 65.4 & 10.3 & 5.6 & 1.9 & 1.7 & 1.5 & 1.5 & 0.64 & 0.19 & 0.18 & 10.7 & 373 & 879 & 192 & 199 & 156 & 93 & 85 & 49 & 19 & 20 & 11 \\
\hline $\mathrm{AhB}$ & $10-20$ & 68.7 & 11.4 & 6.1 & 2.1 & 1.5 & 1.7 & 1.5 & 0.68 & 0.14 & 0.11 & 5.7 & 374 & 956 & 200 & 217 & 171 & 101 & 81 & 46 & 20 & 16 & 10 \\
\hline $\mathrm{Bw}$ & $30-40$ & 67.1 & 12.7 & 6.9 & 2.1 & 1.5 & 2.3 & 1.5 & 0.60 & 0.07 & 0.10 & 4.9 & 318 & 723 & 150 & 210 & 166 & 142 & 78 & 40 & 24 & 20 & 10 \\
\hline \multirow{2}{*}{$\mathrm{C} 1$} & $50-60$ & 68.5 & 12.0 & 6.2 & 2.2 & 1.5 & 2.2 & 1.4 & 0.55 & 0.08 & 0.11 & 5.0 & 294 & 685 & 142 & 218 & 166 & 141 & 74 & 36 & 26 & 16 & 9 \\
\hline & $70-80$ & 68.7 & 12.1 & 6.1 & 2.3 & 1.5 & 2.2 & 1.5 & 0.54 & 0.09 & 0.11 & 4.8 & 301 & 483 & 124 & 216 & 161 & 137 & 72 & 37 & 28 & 18 & 9 \\
\hline \multirow{2}{*}{ C2 Mottle } & $80-87$ & 69.1 & 11.5 & 6.1 & 2.3 & 1.6 & 2.2 & 1.4 & 0.53 & 0.59 & 0.14 & 4.3 & 311 & 438 & 116 & 225 & 140 & 409 & 64 & 35 & 29 & 49 & 8 \\
\hline & 90-100 & 68.8 & 12.0 & 6.3 & 2.2 & 1.6 & 2.3 & 1.4 & 0.55 & 0.06 & 0.12 & 4.3 & 282 & 571 & 125 & 220 & 152 & 138 & 72 & 36 & 30 & 18 & 9 \\
\hline \multirow{2}{*}{$\mathrm{C} 3$} & $110-120$ & 69.0 & 11.6 & 6.2 & 2.4 & 1.7 & 2.2 & 1.4 & 0.58 & 0.07 & 0.12 & 4.4 & 293 & 699 & 137 & 227 & 164 & 134 & 74 & 34 & 24 & 16 & 9 \\
\hline & $120-130$ & 69.0 & 11.7 & 6.4 & 2.3 & 1.7 & 2.3 & 1.4 & 0.59 & 0.07 & 0.12 & 4.3 & 286 & 826 & 150 & 224 & 163 & 135 & 74 & 35 & 25 & 17 & 9 \\
\hline \multicolumn{24}{|c|}{ Buried Soil-Folic Eutric Cambisol (Protocalcic) } \\
\hline Ahb & $0-10$ & 69.0 & 10.9 & 5.3 & 1.9 & 1.9 & 1.6 & 1.7 & 0.64 & 0.15 & 0.11 & 6.5 & 454 & 639 & 230 & 202 & 148 & 87 & 81 & 58 & 26 & 18 & 13 \\
\hline $\mathrm{AhBb}$ & $10-20$ & 70.2 & 11.3 & 5.4 & 1.8 & 1.5 & 1.7 & 1.8 & 0.62 & 0.12 & 0.12 & 5.0 & 427 & 504 & 215 & 186 & 142 & 91 & 71 & 57 & 26 & 23 & 11 \\
\hline Bwb & $20-25$ & 68.0 & 12.2 & 6.2 & 1.7 & 1.5 & 2.0 & 1.8 & 0.63 & 0.09 & 0.11 & 5.5 & 363 & 518 & 212 & 181 & 155 & 108 & 75 & 55 & 24 & 21 & 11 \\
\hline $\mathrm{BCb}$ & $40-50$ & 70.4 & 11.3 & 5.8 & 2.1 & 1.5 & 2.2 & 1.4 & 0.52 & 0.06 & 0.10 & 4.5 & 326 & 603 & 140 & 210 & 164 & 125 & 66 & 38 & 21 & 17 & 9 \\
\hline \multirow{2}{*}{$\mathrm{Cb}$} & $60-70$ & 68.6 & 11.8 & 6.4 & 2.2 & 1.7 & 2.4 & 1.4 & 0.59 & 0.07 & 0.12 & 4.5 & 304 & 938 & 161 & 222 & 169 & 136 & 74 & 35 & 22 & 18 & 9 \\
\hline & $80-90$ & 70.6 & 11.2 & 5.7 & 2.2 & 1.5 & 2.2 & 1.4 & 0.51 & 0.06 & 0.11 & 4.2 & 290 & 660 & 132 & 214 & 165 & 131 & 67 & 36 & 19 & 15 & 9 \\
\hline \multirow[b]{2}{*}{$\mathrm{Ckb}$} & $100-110$ & 70.3 & 11.3 & 5.9 & 2.3 & 1.6 & 2.3 & 1.4 & 0.54 & 0.06 & 0.11 & 4.1 & 321 & 756 & 134 & 222 & 174 & 132 & 69 & 35 & 21 & 18 & 9 \\
\hline & $120-130$ & 66.9 & 11.3 & 6.5 & 2.2 & 3.2 & 2.4 & 1.4 & 0.63 & 0.07 & 0.12 & 5.1 & 275 & 1083 & 157 & 236 & 173 & 134 & 71 & 33 & 21 & 19 & 8 \\
\hline \multicolumn{2}{|c|}{ Loess $[43,44]$} & 74.5 & 11.5 & 3.7 & 1.1 & 1.3 & 1.7 & 2.1 & 0.78 & 0.06 & 0.1 & 3.3 & 435 & 137 & 481 & 145 & 481 & 43 & 62 & 74 & 24 & 29 & 15 \\
\hline
\end{tabular}


The elements $\mathrm{Ti}, \mathrm{Zr}$ and $\mathrm{Nb}$, presumably not lost due to weathering and translocation $[17,40,45]$, were chosen for the detection of lithogenic discontinuities. The ratios of these elements calculated for the soils' parent materials are nearly equal (Table 5), indicating that the sediments had been very likely derived from the same rock source. Additionally, the ratios display very low variations (in most cases less than $15 \%$ ) throughout the soil profiles, which means that lithogenic discontinuities are not present and sediments at each site are relatively homogeneous in terms of their origin [45].

Table 5. Molar ratios of immobile elements in the buried and the surface soils.

\begin{tabular}{ccccc}
\hline \multirow{2}{*}{ Molar Ratio } & \multicolumn{2}{c}{ Parent material, Horizons } & \multicolumn{2}{c}{ Variation Coefficients for the Soil Profiles, \% } \\
\cline { 2 - 5 } & $\begin{array}{c}\text { Ckb Horizon, } \\
\text { Buried Soil }\end{array}$ & $\begin{array}{c}\text { C3 Horizon, } \\
\text { Surface Soil }\end{array}$ & Buried Soil $(\mathbf{n}=\mathbf{8}) *$ & Surface Soil $(\mathbf{n}=\mathbf{9})$ \\
\hline $\mathrm{Ti} / \mathrm{Zr}$ & 46 & 48 & 15 & 11 \\
$\mathrm{Zr} / \mathrm{Nb}$ & 15 & 16 & 12 & 13 \\
\hline \multicolumn{5}{c}{ *n一number of samples. }
\end{tabular}

The transformation of the upper and middle soil horizons relative to lower parent material strata was evaluated using calculation of eluvial/illuvial coefficients (EIC) for potentially mobile elements such as $\mathrm{Na}, \mathrm{K}, \mathrm{Ca}, \mathrm{Mg}, \mathrm{Fe}$, and $\mathrm{Mn}$. The $\mathrm{Ah}$ and $\mathrm{Bw}$ horizons of the two soils showed negative values of EIC for most elements (Figure 9), indicating that the two soils underwent leaching processes. Due to biological cycling, the surficial horizons displayed a poorer leaching of $\mathrm{Ca}$ and $\mathrm{K}$ and strong accumulation of $\mathrm{Mn}$. The very high positive values registered for $\mathrm{Mn}$ in the uppermost horizon of the surface soil stress the biogenic addition of the element from decomposing litter material. In the buried soil, the maximum accumulation of Mn also occurred in the surface horizon. The deeper Bw horizons display positive but smaller values of EIC for Mn, especially in the Bw horizon of the surface soil.

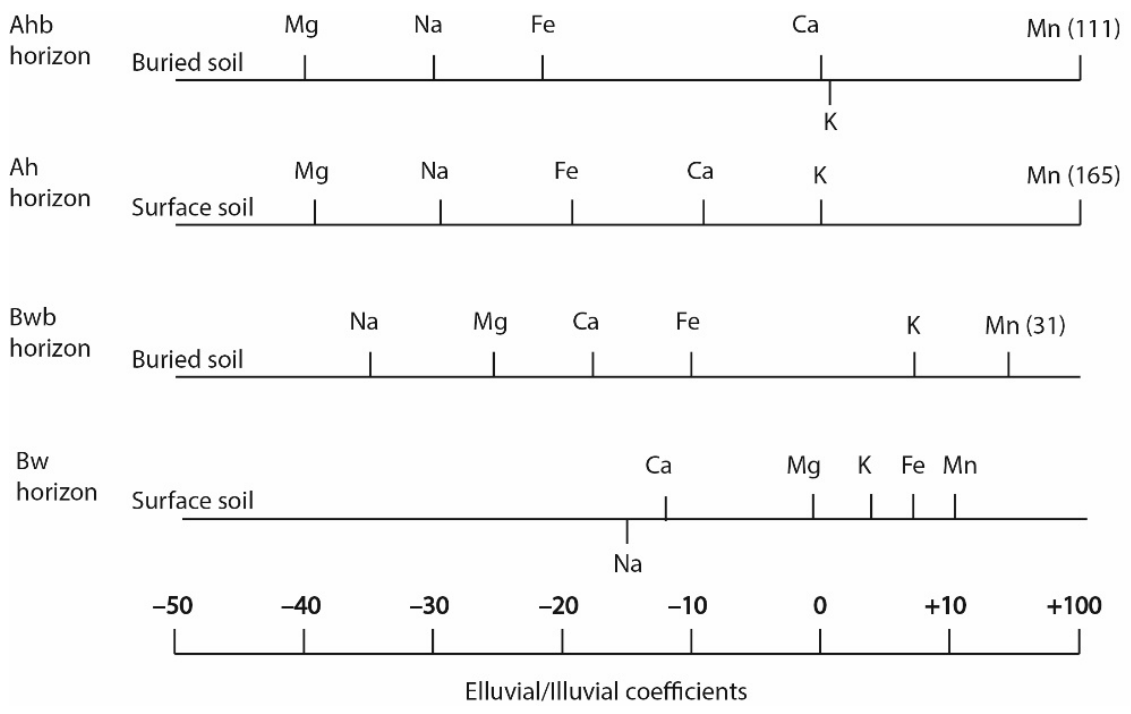

Figure 9. Elluvial/illuvial coefficients for the buried and the surface soils.

Iron fractions (Table 6). Iron oxides and hydroxides, being products of weathering and soil processes, provide an indication of the duration of pedogenesis and are widely used as a paleoclimatic proxy $[46,47]$. In the surface soil, the proportions of pedogenic, or free, iron (Fed) vary between 51 and $39 \%$ of the total iron concentrations, while in the buried soil they range from 43 to $29 \%$. The higher proportions of pedogenic iron in the surface soil agrees with the longer duration of pedogenesis. The oxalate extractable (non-crystalline) iron makes up only a small proportion of the pedogenic iron in both soils, indicating a low iron activity index (Table 6). The highest values of iron activity index are observed in the surface soil, in its humus Ah horizon, resulting from the element biogenic addition, 
as well as at a depth of $80-87 \mathrm{~cm}$, due to the presence of a strongly altered sandstone fragment. In the buried soil, the values of the iron activity index are generally lower compared to the surface soil, however, the Bwb horizon displays a higher iron activity relative to the similar horizon of the surface soil. At the same time both $\mathrm{Bw}$ and Bwb horizons appear to be rich in silicate forms of iron relative to other horizons.

Table 6. Iron (FeO) fractions in the surface and buried soils, \%.

\begin{tabular}{|c|c|c|c|c|c|c|c|c|}
\hline \multirow{2}{*}{ Horizon } & \multirow{2}{*}{ Depth (cm) } & \multirow{2}{*}{$\mathrm{Fe}_{\mathrm{d}}$} & \multirow{2}{*}{$\mathrm{Fe}_{\mathrm{o}}$} & \multirow{2}{*}{$\mathrm{Fe}_{\mathrm{c}}$} & \multirow{2}{*}{$\mathrm{Fe}_{\mathrm{s}}$} & \multicolumn{3}{|c|}{ Weathering Indexes } \\
\hline & & & & & & $\mathrm{Fe}_{\mathrm{o}} / \mathrm{Fe}_{\mathrm{d}}$ & $\mathrm{Fe}_{\mathrm{d}} / \mathrm{Fe}_{\mathrm{s}}$ & $\mathrm{Fe}_{\mathrm{d}} / \mathrm{Fe}_{\mathrm{t}}$ \\
\hline \multicolumn{9}{|c|}{ Surface Soil-Folic Eutric Cambisol } \\
\hline $\mathrm{Ah}$ & $0-10$ & 2.58 & 0.27 & 2.31 & 2.44 & 0.10 & 1.06 & 0.51 \\
\hline $\mathrm{AhB}$ & $10-20$ & 2.72 & 0.2 & 2.52 & 2.79 & 0.07 & 0.98 & 0.49 \\
\hline Bw & $30-40$ & 2.42 & 0.08 & 2.34 & 3.80 & 0.03 & 0.64 & 0.39 \\
\hline \multirow[t]{2}{*}{$\mathrm{C} 1$} & $50-60$ & 2.31 & 0.07 & 2.24 & 3.28 & 0.03 & 0.70 & 0.41 \\
\hline & 70-80 & 2.1 & 0.08 & 2.02 & 3.38 & 0.04 & 0.62 & 0.38 \\
\hline \multirow[t]{2}{*}{$\mathrm{C} 2$} & $80-87$ mottle & 2.26 & 0.2 & 2.06 & 3.20 & 0.09 & 0.71 & 0.41 \\
\hline & 90-100 & 2.23 & 0.06 & 2.17 & 3.46 & 0.03 & 0.65 & 0.39 \\
\hline \multirow{2}{*}{$\mathrm{C} 3$} & $110-120$ & 2.39 & 0.04 & 2.35 & 3.22 & 0.02 & 0.74 & 0.43 \\
\hline & $120-130$ & 2.29 & 0.04 & 2.25 & 3.46 & 0.02 & 0.66 & 0.40 \\
\hline \multicolumn{9}{|c|}{ Buried Soil-Folic Eutric Cambisol (Protocalcic) } \\
\hline Ahb & $0-10$ & 2.21 & 0.15 & 2.06 & 2.57 & 0.07 & 0.86 & 0.46 \\
\hline $\mathrm{AhBb}$ & $10-20$ & 2.12 & 0.16 & 1.96 & 2.76 & 0.08 & 0.77 & 0.43 \\
\hline Bwb & $20-25$ & 1.93 & 0.13 & 1.80 & 3.61 & 0.07 & 0.53 & 0.35 \\
\hline $\mathbf{B C b}$ & $40-50$ & 2.07 & 0.04 & 2.03 & 3.14 & 0.02 & 0.66 & 0.40 \\
\hline \multirow{2}{*}{$\mathrm{Cb}$} & $60-70$ & 2.37 & 0.04 & 2.33 & 3.36 & 0.02 & 0.70 & 0.41 \\
\hline & 80-90 & 1.67 & 0.03 & 1.64 & 3.47 & 0.02 & 0.48 & 0.33 \\
\hline \multirow{2}{*}{$\mathrm{Ckb}$} & $100-110$ & 1.75 & 0.02 & 1.73 & 3.51 & 0.01 & 0.50 & 0.33 \\
\hline & $120-130$ & 1.7 & 0.02 & 1.68 & 4.17 & 0.01 & 0.41 & 0.29 \\
\hline
\end{tabular}

$\mathrm{Fe}_{\mathrm{t}}$-total iron $\left(\mathrm{Fe}_{\mathrm{o}}\right)$ content; $\mathrm{Fe}_{\mathrm{d}}$-dithionite extractable (free) iron; $\mathrm{Fe}_{\mathrm{o}}$-oxalate extractable (active) iron; $\mathrm{Fe}_{\mathrm{s}}$ - silicate iron $\left(\mathrm{Fe}_{\mathrm{t}}-\mathrm{Fe}_{\mathrm{d}}\right) ; \mathrm{Fe}_{\mathrm{c}}$-crystalline iron $\left(\mathrm{Fe}_{\mathrm{d}}-\mathrm{Fe}_{\mathrm{o}}\right) ; \mathrm{Fe}_{\mathrm{o}} / \mathrm{Fe}_{\mathrm{d}}$-iron activity index; $\mathrm{Fe}_{\mathrm{d}} / \mathrm{Fe}_{\mathrm{s}}$-weathering index.

Palynological data. Grass pollen and spores constitute relatively small proportions in the total pollen and spore spectrum of the two soils. In the surface soil, spores are absent, and grass pollen make up $6 \%$, while in the buried soil the share of grass pollen and spores is nearly the same $(5 \%$ of the total spectrum). The proportion of spores in the buried soil, indicating humid conditions, reaches $8 \%$ in the western wall and $1 \%$ in the northern wall.

In the pollen spectra of the surface and the buried soils, arboreal pollen are dominant. In the surface soil, trees account for $94 \%$ of the total spectrum, while in the buried soil they vary between $87-94 \%$. Pollen of birch is dominant in both soils, in the surface soil representing $90 \%$ and in the northern wall of the buried soil 92\% (Figure 10). Pollen of broadleaf trees (oak, lime) and also Corylus, a typical shrub in broadleaf forests, are rare in both soils; however, in the present-day forest community they are dominant species. An admixture of conifers occurs in the pollen spectrum of both the surface and the buried soils (Figure 10). In the buried soil, pollen of pine (73\%) and spruce (2\%) were identified in the topsoil of the western wall, showing a reliable presence of coniferous trees in this location. In the northern wall only pine grains in minor quantities $(2 \%)$ were found.

According to phytolith analysis (Table 7), needles of coniferous trees were found in the upper 0-2 and $0-3 \mathrm{~cm}$ of both soils, confirming the possibility of the soils' development under coniferous or mixed forest communities. The composition of the phytolith complexes in the two samples of the uppermost layers $(0-2 \mathrm{~cm})$ of the surface soil is very similar. In both samples herbaceous cenoses predominate, while phytoliths of conifers are corroded in comparison to the herbaceous forms, implying the possible replacement of coniferous or mixed forest cenoses in the past by broadleaf forest with herbaceous layer. In the buried soil, the uppermost layers $(0-3 \mathrm{~cm})$ display many forms derived from the forest complex, 
including needles of conifers but also steppe grasses. However, in the deeper horizon $(3-7 \mathrm{~cm})$ the contribution of the steppe complex component increases. In the grave material some components indicating wet habitats (reed and sedges) were found. This "wet" complex is typical of riverine landscapes. The traces of such wet complex were also found in the upper $3 \mathrm{~cm}$ in the northern wall of the buried soil, suggesting its pollution by foreign (transferred) material during the burial ritual.

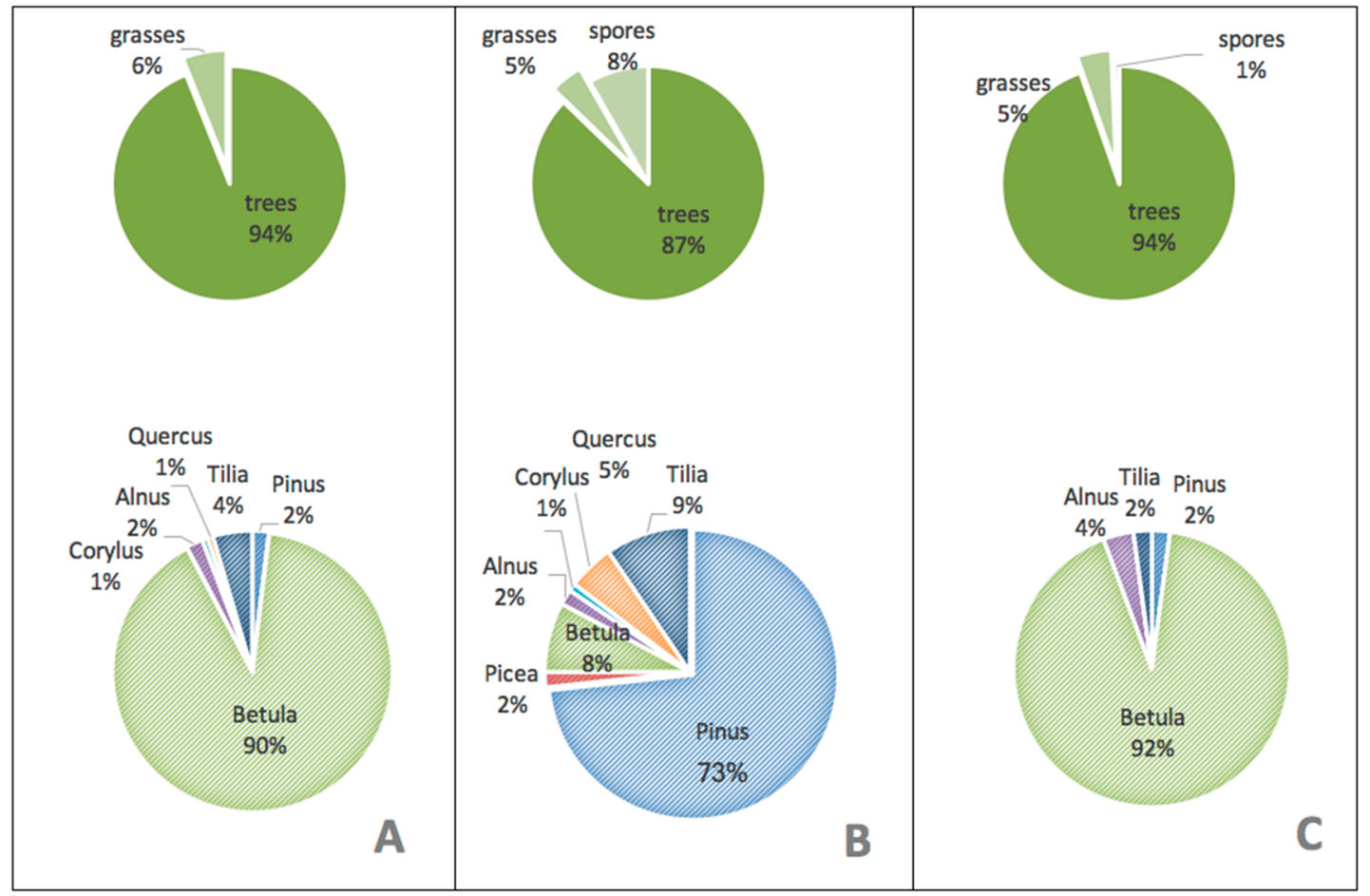

Figure 10. Total pollen and spore spectrum and the pollen spectrum of the tree and shrub species in the upper 0-5 cm layers of the surface soil (A) and the buried soil in its western (B) and northern wall (C).

Table 7. Silica microbiomorphs and individual groups of phytolites.

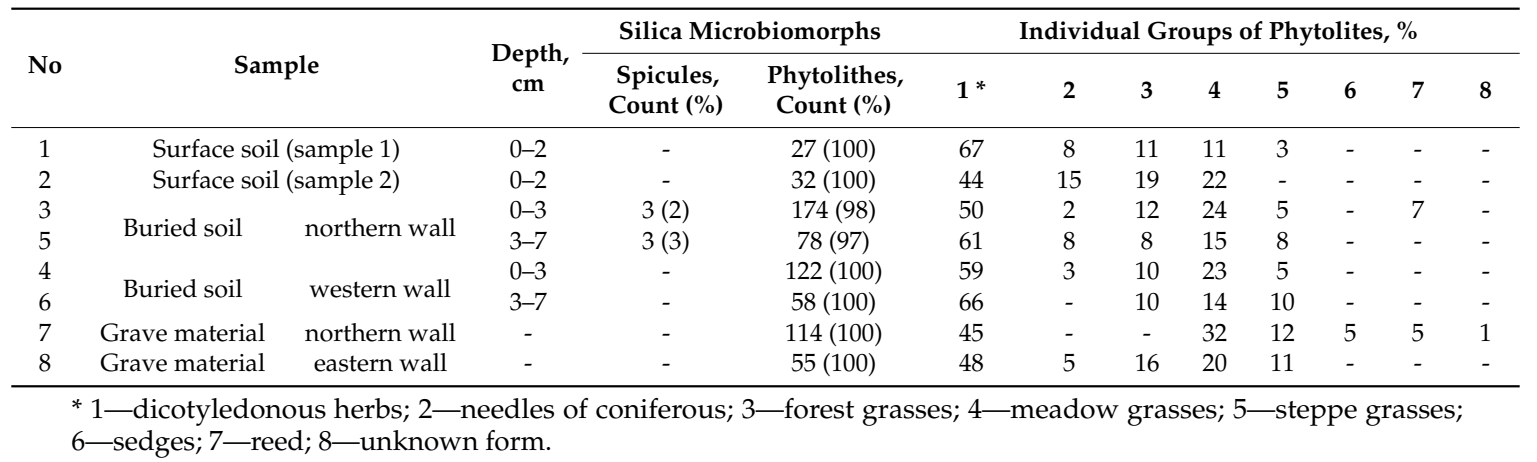

\section{Discussion}

Both the surface soil and the buried soil are classified as Folic Eutric Cambisols, formed in similar parent material consisting of unconsolidated deposits derived from Upper Permian sandstones. Fragments of altered sandstone are well preserved in the lower parts of both profiles. The grain size distribution revealed noticeable differences, allowing to distinguish two main layers within the soil profiles-an upper layer, $50-\mathrm{cm}$ thick, and a lower (basal) layer, hosting the $\mathrm{C}$ horizons. The basal layer in both soils has a coarser texture dominated by the fine and very fine sand representing non-transported sandstone residuum. The total sand content in the $C$ horizons (80-85\%) does not vary significantly from site-to-site, indicating a textural uniformity of the basal layer along the slope. 
The morphological features of the basal layer are largely controlled by the properties of the underlying sandstone plate. On a microscopic level, the $\mathrm{C}$ horizons of both soils showed traces of horizontal laminations inherited from the bedrock. The upper layers of the studied soils, hosting soil horizons, are also dominated by the sand fractions, but they have higher amounts of finer material compared to the basal layer, which is interpreted as a result of pedogenesis and weathering processes. In spite of the similarity in texture of the upper layers, the clay content varies, with the buried soil revealing a higher amount of clay (19-24\%) compared to the surface soil (17-15\%). These variations we relate to minor redistribution of fine material along the slope. The increase in the silt content, detected in the upper $20 \mathrm{~cm}$ in both soils, may be a result of pedogenic processes and also aeolian input; although, the coarse silt to clay ratio, used for evaluating aeolian particles addition [48] is less than 1, indicating that the input of allochthonous (aeolian) material was too small, especially in the buried soil, to have a notable impact on the properties of soils. The absence of distinct lithological discontinuities related to different genetic sources of the soil parent material was also confirmed by low variations $(\mathrm{Cv}<15 \%)$ of the immobile element ratio $[40,45]$.

Chemical analysis of the basal layer revealed specific features in its elemental composition, indicating the distinct difference of the sediments in the study area from decalcified loess, and having an impact on pedogenic processes. The sandstone residua showed to be richer in alkaline and alkaline earth elements $(\mathrm{Na}, \mathrm{Ca}, \mathrm{Mg}$ ) as well as Fe. Because of the relatively high content of $\mathrm{Ca}$ and $\mathrm{Mg}$, the buried and surface soils reveal high base saturation with the predominance of bivalent ions (98.4-100\% and $97.8-99 \%$, respectively). The absorption of $\mathrm{Ca}^{2+}$ on exchangeable sites favors the coagulation of the colloids and inhibits lessivage until bases are removed [17,49]. The same effect is caused by the presence of soil cements such as iron, manganese, silicon, and aluminium oxides, which reduce soil dispersibility by binding soil particles [49]. As a result, the argillans providing clear environmental information associated with a humid leaching regime, seem to be poorly developed or even absent.

In the surrounding areas, the surface soils and the paleosols of the Early Iron age derived from decalcified loess $[50,51]$ have distinct Argic horizon and multi-layered clay cutans. The morphological study of the two soils developed in Upper Permian sandstone residuum showed the absence of readily visible features of clay illuviation but the examination of thin sections of both soils revealed different features: the buried Bronze age soil, in contrast to the surface soil, showed some signs of material translocation manifested as oriented clay with high birefringence and thin cutans in the Bwb horizon. However, the index of textural differentiation (ITD), calculated as the ratio of the clay-sized fine material in the Bwb and the overlying AhBb horizons, was too low (ITD $<<1.4$ ) to denominate the horizon as Argic [23]. The question why clay cutans, being persistent signatures of a humid environment, were not found in the surface soil might be explained by the insufficient amount of the fine material in its surface horizons [52]. Our data support the idea that the lower clay content of the surface soil (16-17\%) probably was less favorable for clay illuviation processes compared to the slightly higher amount of clay-size particles in the buried soil (19-20\%) but the presence of clay cutans in the soil buried approximately 4000 years BP provides a reliable evidence of humid environmental conditions during its formation.

Other evidence of climatically humid conditions during the development of the paleosol are the elluvial/illuvial coefficients (EIC) calculated for the basic elements and Fe and their depth functions, confirming that both soils underwent leaching regimes. However, the leached zones are rather shallow and restricted only to the upper $40-50 \mathrm{~cm}$. According to the EIC values, the Ah and Ahb horizons show a greater total loss of $\mathrm{Mg}, \mathrm{Na}, \mathrm{Fe}$ than the subsurface horizons. Due to biological cycling the surficial horizons also displayed a poor leaching of $\mathrm{Ca}$ and $\mathrm{K}$ and strong accumulation of Mn (Figure 9), the element which is strongly involved in biocycling by some arboreal species in subtaiga zone $[53,54]$. The Bw and Bwb horizons also show the leaching of bases, but reveal insignificant loss or even a slight accumulation of total Fe. 
The reaction of soil solutions in the surface soil profiles is comparable to the leaching patterns, varying from weakly acidic in upper horizons to neutral in the lower stratum. In the buried soil, reactions were moderately alkaline to strongly alkaline. The shift to alkalinity is a result of buried soil diagenesis [13] and incomplete leaching of calcium carbonates. The $\mathrm{pH}$ values show good agreement with the $\mathrm{CaCO}_{3}$ distribution. In the surface soil, carbonates are completely leached from the profile except for the lower strata and large mottles, where $\mathrm{CaCO}_{3}$ content is detectible due to the presence of calcareous fragments inherited from the parent material. In the buried soil, carbonates are disseminated throughout the profile, showing a maximum of about $1 \%$ in the lowermost horizon $\mathrm{Ckb}$. Thin sections studies revealed that calcium carbonates appear only as geogenic forms in the surface soil, while in the buried soil both geogenic and secondary carbonates are identified, the latter can be seen as micritic nodules inside the groundmass and as coatings on the wall of weakly developed voids.

Distinct differences between the two soils were found when comparing their upper Ah and Ahb horizons, including color, humus amount, the intensity of bioturbation, as well as humus types and forms. The Ahb horizon contains less organic matter than the Ah horizon in the surface soil, but at the same time the buried A horizon has a darker color, a higher humus quality and higher degree of bioturbation. The reasonably low C:N ratio in the topsoil of the buried soil implies that all easily and decomposable organic substances have been completely biomineralized in the process of burial, while more resistant substances have relatively accumulated. Based on a large number of observations, Ivanov et al. [55] calculated the loss of organic carbon in different-age buried chernozems. The estimates revealed that biomineralization after the first 200-300 years of the soil being buried leads to a $30 \%$ loss of the original organic carbon content, and an additional 30-35\% loss occurs during the following 3000-4000 years. Accordingly, this indicates that the initial amount of SOM in the buried soil could have exceeded $8 \%$.

According to the ratio between carbon contents in the two humus components-humic and fulvic acids-the buried soil has a humate type of organic matter, with a very strong prevalence of stable humic acids $\left(\mathrm{C}_{\mathrm{HA}} / \mathrm{C}_{\mathrm{FA}}=5\right)$, while in the surface soil the ratio between carbon of humic and fulvic acids nearly equals 1 , which is very typical for a deciduous forest environment. The strong enrichment of the topsoil of the buried soil with humic acids can be explained by their initial dominance over the fulvic fraction, since the complete biomineralization of fulvic acids after the soil's burial, could have led only to a two-fold increase of the ratio value. The thin sections show that in terms of mixing of organic material with the mineral soil, humus in the buried soil is more bioturbated and belongs to the mull form, while in the surface soil it belongs to the moder form. Thus, analytical and micromorphological data confirm the prominent differences in the features and origin of organic material in the contemporary surface soil and the paleosol, showing that the humus horizons of the two soils originated under different conditions, specifically that the humus of the Bronze age soil originated in an ecosystem with higher biological activity and under more productive vegetation.

More direct evidence of land cover can be provided by palynological analysis, however it is known that pollen can undergo severe deterioration caused by oxidation, microbial attack and high $\mathrm{pH}$ [56], leading to an alteration in the relative abundance of taxa which impacts any pollen-based reconstruction of paleovegetation. A study of pollen assemblages in Chinese loess samples collected in different areas [56] revealed that Artemisia, Aster, Poaceae, Pinus and Chenopodiaceae belong to the dominant types in the pollen spectra because of their relative resistance to decay, while deciduous taxa, such as Betula, Quercus, Ulmus, and Corylus are more susceptible to destruction and always occur in low percentages. Our investigation of the pollen assemblages of the two soils confirms that the soils developed under forest vegetation. The pollen of oak and lime, preserved in the buried soil in quantities similar to the surface soil, reliably indicate the wide occurrence of broadleaf species in the past [56,57]; however, the presence of pollen of coniferous taxa (spruce and pine) indicated the development of more complex coniferous-broadleaf communities in the past. The high proportion of birch pollen (also susceptible to the decay but produced in large quantities) both in the buried and the surface soils assumes the existence of birch stands in the past [57]. In the forest belt, birches 
often are regarded as pioneer species, rapidly colonizing open land spaces, especially in secondary successions following a disturbance or fire [54]. At the same time birch often occurs as an admixture in coniferous-broadleaf and coniferous forests.

Phytoliths are fairly resistant to decomposition. They are liberated by plants during normal decay and enter the soil with plant litter [33-36]. The phytolith analysis, which provides a signature of local flora, revealed some general trends in plant communities' successions. The phytoliths in the Bronze age soil at the $0-3 \mathrm{~cm}$ depth display many forms derived from the forest complex, including needles of conifers but also steppe grasses. However, in the deeper horizon $(3-7 \mathrm{~cm})$, referring to the earlier stages of soil development, the contribution of components from the steppe complex increases. In the surface soil, the phytolith analysis shows some shifts from more humid coniferous or mixed forest complex to the deciduous forest with a herbaceous layer.

Summarizing the results of the morphological and analytical studies, it can be concluded that both soils with poorly differentiated profiles were formed in a parent material with relatively low sensitivity to bioclimatic factors [52]. The parent material consists of sediments that must have originated from one source - the underlying calcareous sandstone of the Upper Permian age with relatively high contents of base elements and total iron. The sediments at the studied sites consist of two spatially similar layers which differ in texture. The lower part represents the sandstone's coarser residua with a preserved sedimentary lamination and geogenic carbonates in its basal layer, while the upper part, $40-50 \mathrm{~cm}$ thick, contains a higher amount of clay particles and hosts the Ah, AhB, Bw, and BC horizons. Both soils have many similar features that indicate their development mostly in a forested environment. However, the properties of the upper horizon of the Bronze Age paleosol also imply that it survived a warmer and drier (subhumid) stage of pedogenesis, probably in Late Atlantic period. The aridization of climate conditions during this period with probable shifts from forest to steppe environment [58] has been registered earlier in the paleosols of the Middle Volga [59] and forest-steppe areas of the Russian Plain [6]. In the buried soil, this warmer and drier stage resulted in the formation of secondary carbonates, as clearly seen at the microscopic level, and in the development of the bioturbated Ahb horizon, with dark mull humus enriched in stable humic acids. However, the absence of krotovinas, the low thickness of the Ah horizon of the buried soil and pollen and phytholith assemblages indicate that pedogenesis during this stage took place not in a steppe environment but rather in subhumid open deciduous or mixed forest with a thick herbaceous layer including steppe grasses. The shift to a more humid pedogenic stage in soil development probably occurred in the Subboreal period prior to the construction of the Bronze-age kurgan. According to the previous studies $[8,60]$, phases of humidization in the central parts of the forest-steppe zone were accompanied by the advancements of forest vegetation onto steppe interfluves. During this stage, the soils of the study site, located more to the north from the ecotone area, were developing under denser mixed (broadleaf-coniferous, deciduous-coniferous) forest with less involvement of steppe grasses compared to the previous period. So the results of our study made it possible to reconstruct smaller differences and nuances in environment. In spite of the low-reactive parent material, limiting the development of an Argic horizon, the increase in humidity can be seen on the microscopic level as weak Luvic features (cutans) in the Bwb horizon. During the next pedogenic stage, a humid forest environment continued to be dominant, although some fluctuations might have occurred, as the microbiomorphic analysis revealed the shifts from mixed coniferous paleovegetation to the deciduous forest with a thicker herbaceous cover. Our earlier studies [44] of a paleosol buried under a fortification earth wall in the vicinity ( $60 \mathrm{~km}$ from the study site) confirmed the relative stability of the forested environment over the period from the Early Iron Age until present. As shown by the properties of the surface soil, the former humic horizon has been transformed and substituted with a horizon typical for a deciduous forest environment. The progressive development of Luvic features in the surface soil however was limited by both the chemical and textural features of the parent material. 


\section{Conclusions}

The study of the soil chronosequence at the southern frontier of the forest belt in the Middle Volga region clearly showed the similarity of soils and landscapes through the time interval of the last 4000 years. Despite the complex soil pattern in the close vicinity of the study site, the investigated soils display relatively poor soil development and the lack of distinct polygenetic features. The impact of the climatic changes on soil morphology and properties, which have been registered in soil chronosequences in the northern, central and southern parts of the forest-steppe zone of the Russian Plain, was smoothed by two factors: (1) the buffering effect of non-reactive parent material, inhibiting the development of certain pedogenic processes and (2) the similarity of vegetation cover during the studied time interval. On the basis of analytical, palynological and pytolithic data, it can be concluded that both soils developed under forest communities, were affected by minor variations in precipitation and temperature. The shift from more open forests to denser forests following an increase in humidity was detected in the microbiomorphic analysis. The pedo-signature of the subhumid period was preserved in the humus horizon of the buried soil, showing higher quality humus, more intensive bioturbation and a darker color. We suggest that this stage occurred in the Late Atlantic period, while the subsequent increase in moisture content took place in the Subboreal period prior to the burial of the soil, recorded in the soils' middle horizons as weak illuvial clay features.

Author Contributions: E.A., A.M., F.K., P.K., A.R. and O.K. performed the fieldwork and soil sampling; E.A., A.M., F.K., P.K. and O.K. wrote the paper; E.M. organized the excavation and provided all the archaeological information; P.K. performed micromorphological analysis; T.P. organized the field work; A.G. carried out the phytolith analysis; and all together we discussed the obtained data and corrected the text.

Funding: This research was funded by the Russian Science Foundation, grant number 16-17-10280.

Acknowledgments: We would like specially thank E.G. Ershova for spore-and-pollen analysis and H.J.L. Leummens for the discussion of the paper.

Conflicts of Interest: The authors declare no conflict of interest. The funding sponsors did not take part in the design of the study; in the collection, analyses, or interpretation of data; in the writing of the manuscript; or in the decision to publish the results.

\section{References}

1. Alekseeva, T.; Alekseev, A.; Maher, B.A.; Demkin, V. Late Holocene climate reconstructions for the Russian steppe, based on mineralogical and magnetic properties of buried palaeosols. Palaeogeogr. Palaeoclim. Palaeoecol. 2007, 249, 103-127. [CrossRef]

2. Ivanov, I.V.; Tabanakova, E.D. Changes in the thickness of humus horizons and the Holocene evolution of East European chernozems (mechanisms, factors, and regularities). Eurasia. Soil Sci. 2003, 36, 917-930.

3. Demkin, V.A.; Demkina, T.S.; Borisov, A.V.; Yakimov, A.S.; Sergatskov, I.V. Transformation of soils and environmental conditions in the semidesert low Volga region within the past 4000 years. Eurasia. Soil Sci. 2004, 37, 230-241.

4. Khokhlova, O.S.; Kovalevskaya, I.S.; Oleynik, S.A. Records of climatic changes in the carbonate profiles of Russian Chernozems. Catena 2001, 43, 203-215. [CrossRef]

5. Khokhlova, O.S.; Khokhlov, A.A.; Oleynik, S.A.; Gabuev, T.A.; Malashev, V.Y. Paleosols from the groups of burial mounds provide paleoclimatic records of centennial to intercentennial time scale: A case study from the Early Alan cemeteries in the Northern Caucasus (Russia). Catena 2007, 71, 477-486. [CrossRef]

6. Rusakov, A.V.; Makeev, A.O.; Khokhlova, O.S.; Kust, P.G.; Lebedeva, M.P.; Chernov, T.I.; Golyeva, A.A.; Popov, A.I.; Kurbanova, F.G.; Puzanova, T.A. Paleoenvironmental reconstruction based on soils buried under Scythian fortification in the southern forest-steppe area of the East European Plain. Quat. Int. 2018, 1-21, in press. [CrossRef]

7. Alexandrovskiy, A.L.; Glasko, M.P.; Krenke, N.A.; Chichagova, O.A. Buried soils of floodplains and paleoenvironmental changes in the Holocene. Revista Mexicana de Ciencias Geologicas 2004, 21, 9-17.

8. Chendev, Y.G.; Aleksandrovskiy, A.L.; Khokhlova, O.S.; Dergacheva, M.I.; Petin, A.N.; Golotvin, A.N.; Sarapulkin, V.A.; Zemtsov, G.L.; Uvarkin, S.V. Evolution of forest pedogenesis in the south of the forest-steppe of the Central Russian Upland in the Late Holocene. Eurasia. Soil Sci. 2017, 50, 1-13. [CrossRef] 
9. Khokhlova, O.S.; Kuptsova, L. Complex pedological analysis of paleosols buried under kurgans as a basis for periodization of the Timber-grave archaeological culture in the Southern Cis-Ural, Russia. Quat. Int. 2018, in press. [CrossRef]

10. Alexandrovskiy, A.L.; Chichagova, O.A. Radiocarbon age of Holocene paleosols of the East European forest-steppe zone. Catena 1998, 34, 197-207. [CrossRef]

11. Panin, A.V.; Fuzeina, J.N.; Belyaev, V.R. Long-term development of Holocene and Pleistocene gullies in the Protva River basin, Central Russia. Geomorphology 2009, 108, 71-91. [CrossRef]

12. Panin, A.; Fuzeina, Y.; Karevskaya, I.; Sheremetskaya, E. Mid-Holocene gullying indicating extreme hydroclimatic events in the center of the Russian Plain. Geogr. Pol. 2011, 84, 95-115. [CrossRef]

13. Ivanov, I.V. Evolution of Soils in the Steppe Zone during the Holocene; Pulbishing House Science: Moscow, Russia, 1992; p. 145. (In Russian)

14. Demkin, V.A. Paleopedology and Archaeology: Integration of the Studies of the History of Nature and Society; ONTI PNC RAS Press: Pushchino, Russia, 1997; p. 212. (In Russian)

15. Bolshov, S.V. Problems of Middle Bronze age culture formation in the forest zone of the middle Volga region. News Samara Cent. Sci. Russ. Acad. Sci. 2007, 9, 509-514. (In Russian)

16. Anthony, D.W. The Horse, the Wheel, and Language: How Bronze-Age Riders from the Eurasian Steppes Shaped the Modern World; Princeton University Press: Princeton, NJ, USA, 2007; p. 553.

17. Schaetzl, R.J.; Anderson, S. Soils: Genesis and Geomorphology; Cambrige University Press: Cambridge, UK, 2005; p. 817.

18. Mihailov, E.P.; Berezina, N.S.; Beresin, A.Y.; Kuzminych, S.V.; Myasnikov, Y.S.; Kakhovski, V.F.; Kakhovski, B.V. Archaeological Map of Chuvash Republic, V. 2; Chuvash Publishing House: Cheboksary, Russia, 2014; p. 312. (In Russian)

19. Geological Map and Map of Minerals of Pre-Quaternary Formations, 1: 200 000, N-38-VI. Available online: http:/ / geo.mfvsegei.ru/200k/n-38/n-38-6/1/index.html (accessed on 8 September 2018).

20. Map of Quaternary deposits, 1: 200 000, N-38-VI. Available online: http://geo.mfvsegei.ru/200k/n-38/n38-6/3/index.html (accessed on 8 September 2018).

21. Gribova, S.A.; Isachenko, T.I.; Lavrenko, E.M. Vegetation of the European Part of the USSR; Publishing House Nauka-Press: Leningrad, Russia, 1980; p. 236. (In Russian)

22. State Soil Map. Sheet N-38. Scale 1:1 000 000; V.V. Dokuchaev Soil Science Institute, Academy of Sciences of the USSR; GUGK Publisher: Moscow, Russia, 1953.

23. IUSS Working Group WRB. World Reference Base for Soil Resources 2014-International Soil Classification System for Naming Soils and Creating Legends for Soil Maps, Update 2015; World Soil Resources Reports 2015, No. 106; Food and Agriculture Organization of the United Nations: Roma, Italy, 2015.

24. Climate: Tsivilk. Available online: https://ru.climate-data.org/location/37159/ (accessed on 15 October 2018).

25. FAO Guidelines for Soil Description, 4th ed.; Food and Agriculture Organization of the United Nations: Roma, Italy, 2006; p. 109.

26. Stoops, G. Guidelines for the Analysis and Description of Soil and Regolith Thin Sections; Soil Science Society of America: Madison, WI, USA, 2003; p. 184.

27. Arinushkina, E.M. Handbook for Chemical Analysis of Soils; Chimiya Publishing House: Moscow, Russia, 1992; p. 425. (In Russian)

28. Van Reeuwijk, L.P. Procedures for Soil Analysis, 3rd ed.; International Soil Reference and Information Centre: Wageningen, The Netherlands, 1992; p. 94.

29. Shein, E.V. The particle-size distribution in soils: Problems of the methods of study, interpretation of the results, and classification. Eurasian Soil Sci. 2009, 42, 284-291. [CrossRef]

30. Martín, M.Á.; Pachepsky, Y.A.; García-Gutiérrez, C.; Reyes, M. On soil textural classifications and soil-texture-based estimations. Solid Earth 2018, 9, 159-165. [CrossRef]

31. Ponomareva, V.V.; Plotnikova, T.A. Methodological Recommendations for Determination of the composition of Humus in Peat and Mineral Soils; Publishing House Nauka: Leningrad, Russia, 1975; p. 105. (In Russian)

32. Mehra, O.P.; Jackson, M.L. Iron oxide removal from soils and clays by dithionitecitrate system buffered with sodium bicarbonate. Clays Clay Miner. 1960, 32, 557-563.

33. Piperno, D.R. Phytolith Analysis: An Archaeological and Geological Perspective; Academic Press: San Diego, CA, USA, 1988; p. 280. 
34. Golyeva, A.A. Biomorph analysis as constituent part of genetic and morphological soil study. Soil Sci. 1997, 9, 1045-1055. (In Russian)

35. Golyeva, A.A. Biomorphic analysis as a part of soil morphological investigations. Catena 2001, 43, $217-230$. [CrossRef]

36. Peto, A. Burial mound: Detecting ancient surfaces the method of (semi)quantitative phitolith and biomorph analysis. Archeologia e Calcolatori 2010, 21, 315-324.

37. Moore, P.D.; Webb, J.A.; Collinson, M.D. Pollen Analysis, 2nd ed.; Blackwell: Oxford, UK, 1991; p. 216.

38. Beug, H.-J. Leitfaden der Pollenbestimmung für Mitteleuropa und Angrenzende Gebiete; Verlag Friedrich Pfeil: Munich, Germany, 2004; pp. 482-487.

39. Eckmeier, E.; Gerlach, R.; Gehrt, E.; Schmidt, M.W.I. Pedogenesis of chernozems in Central Europe-A review. Geoderma 2007, 139, 288-299. [CrossRef]

40. Sheldon, N.D.; Tabor, N.J. Quantitative paleoenvironmental and paleoclimatic reconstruction using paleosols. Earth-Sci. Rev. 2009, 95, 1-52. [CrossRef]

41. Muir, J.W.; Logan, J. Eluvial/illuvial coefficients of major elements and the corresponding losses and gains in three soil profiles. J. Soil Sci. 1982, 33, 295-308. [CrossRef]

42. Rozanov, B.G. Morphology of Soils; Academic Project Press: Moscow, Russia, 2004; p. 432. (In Russian)

43. Vasiliev, O.A. Eroded Soils of the Chuvash Republic and Its Reclamation. Ph.D. Thesis, Saint-Petersburg State University, Saint-Petersburg, Russia, 2007; p. 327. (In Russian)

44. Makeev, A.O.; Aseyeva, E.N.; Rusakov, A.V.; Sorokina, K.I.; Puzanova, T.A.; Khokhlova, O.S.; Kust, P.G.; Kurbanova, F.G.; Chernov, T.I.; Kutovaya, O.V.; et al. The environment of the Early Iron Age at the southern fringe of the forest zone of the Russian Plain. Quat. Int. 2018, 1-20, in press. [CrossRef]

45. Marsan, F.A.; Bain, D.C.; Duthie, D.M.L. Parent material uniformity and degree of weathering in a soil chronosequence, northwestern Italy. Catena 1988, 15, 507-517. [CrossRef]

46. Vodyanitsky, Y.N. Minerals of iron as a memory of soil processes. In Memory of Soils: Soil as A Memory of Biosphere-Geosphere-Anthropospheric Interactions; Targulyan, I.N., Goryachkin, S.V., Eds.; Publishing House LCI: Moscow, Russia, 2008; pp. 288-313. (In Russian)

47. Sauer, D.; Schülli-Maurer, I.; Sperstad, R.; Sørensen, R.; Stahr, K. Albeluvisol development with time in loamy marine sediments of S-Norway. Quat. Int. 2009, 209, 31-43. [CrossRef]

48. Lebedeva, I.I. Granulometric profile of Eastern European chernozems and its differentiation. Pochvovedeniye 1996, 7, 821-829. (In Russian)

49. Quénard, L.; Samouëlian, A.; Laroche, B.; Cornu, S. Lessivage as a major process of soil formation: A revisitation of existing data. Geoderma 2011, 167, 135-147. [CrossRef]

50. Andreev, S.I. Soils of Chuvash Republic; Chuvashknigizdat Publisher: Cheboksary, Russia, 1971; p. 355. (In Russian)

51. Mikhailov, F.Y. Sod-podzolic Soils of Chuvash Republic; Chuvashknigizdat Publisher: Cheboksary, Russia, 1974; p. 154. (In Russian)

52. Lebedeva, I.I.; Tonkonogov, V.D. Memory of genetic horizons and soil profiles. In Memory of Soils: Soil as a Memory of Biosphere-Geosphere-Anthropospheric Interactions; Targulyan, I.N., Goryachkin, S.V., Eds.; Publishing House LCI: Moscow, Russia, 2008; pp. 162-181. (In Russian)

53. Enchilik, P.R.; Aseeva, E.N.; Semenkov, I.N. Biological uptake and biogeochemical mobility of microelements in forest landscapes of Central Forest State Biosphere Nature Reserve. Probl. Reg. Ecol. 2018, 4, 93-98. (In Russian)

54. Isachenkova, L.B.; Tarzayeva, M.V. Comparative biogeochemical characteristics of forest ecosystems. In Ecosystems of Broadleaf-Coniferous Forests in the Southern Part of Moscow Region; Publishing House of Moscow State University: Moscow, Russia, 2006; pp. 84-97. (In Russian)

55. Ivanov, I.V.; Khokhlova, O.S.; Chichagova, O.A. Natural carbon and humus formation in chernozems. Izvestiya Rossiiskoi Akademii Nauk. Seriya Geograficheskaya 2009, 6, 46-58. (In Russian)

56. Zhang, W.; Lu, H.; Li, C.; Dodson, J.; Meng, X. Pollen preservation and its potential influence on paleoenvironmental reconstruction in Chinese loess deposits. Rev. Palaeobot. Palynol. 2017, 240, 1-10. [CrossRef]

57. Sladkov, A.N. Introduction to Spore-Pollen Analysis; Publishing House Nauka: Moscow, Russia, 1967; p. 270. (In Russian) 
58. Chendev, Y.G.; Ershova, E.G.; Alexandrovsky, A.L.; Ponomarenko, E.V.; Gol'eva, A.A.; Khokhlova, O.S.; Rusakov, A.V.; Shapovalov, A.S. Pedological and botanical records of environment changes of Yamskaya Steppe (Belgorod Oblast, Russia) in Holocene. Izvestiya Rossiiskoi Akademii Nauk. Seriya Geograficheskaya 2016, 2, 75-89. (In Russian) [CrossRef]

59. Alexandrovskiy, A.L.; Alexandrovskaya, E.I. Soil Evolution and the Geographic Environment; Publishing House Nauka: Moscow, Russia, 2005; p. 223. (In Russian)

60. Alexandrovskiy, A.L. Records of environment in Holocene Soils. In Memory of Soils: Soil as A Memory of Biosphere-Geosphere-Anthropospheric Interactions; Targulyan, I.N., Goryachkin, S.V., Eds.; Publishing House LCI: Moscow, Russia, 2008; pp. 75-105. (In Russian)

(C) 2019 by the authors. Licensee MDPI, Basel, Switzerland. This article is an open access article distributed under the terms and conditions of the Creative Commons Attribution (CC BY) license (http://creativecommons.org/licenses/by/4.0/). 